\title{
How Useful are Episcopal Ordination Lists as a Source for Medieval English Monastic History?
}

\author{
by DAVID E. THORNTON \\ Bilkent University, Ankara \\ E-mail: tdavid@bilkent.edu.tr
}

This article evaluates ordination lists preserved in bishops' registers from late medieval England as evidence for the monastic orders, with special reference to religious houses in the diocese of Worcester, from 1300 to 1540 . By comparing almost 7,0oo ordination records collected from registers from Worcester and neighbouring dioceses with 178 'conventual' lists, it is concluded that over 25 per cent of monks and canons are not named in the extant ordination lists. Over half of these omissions are arguably due to structural gaps in the surviving ordination lists, but other, non-structural factors may also have contributed.

W ith the dispersal and destruction of the archives of religious houses following their dissolution in the late 153 os, many documents that would otherwise facilitate the prosopographical study of the monastic orders in late medieval England and Wales have been irretrievably lost. Surviving sources such as the profession and obituary lists from Christ Church Canterbury and the records of admissions in the

$\mathrm{BL}=$ British Library, London; Bodl. Lib. = Bodleian Library, Oxford; $B R U O=$ A. B. Emden, A biographical register of the University of Oxford to A.D. I50o, Oxford 1957-9; CAP = Collectanea Anglo-Premonstratensia, London 1904; DKR=Annual report of the Deputy Keeper of the Public Records, London 1840-1958; FOR=Faculty Office Register, I532-1549, ed. D. S. Chambers, Oxford 1966; GCL=Gloucester Cathedral Library; $L P=\mathrm{J}$. S. Brewer and others, Letters and papers, foreign and domestic, of the reign of Henry VIII, London 1862-1932; LPL = Lambeth Palace Library, London; $M A=\mathrm{W}$. Dugdale, Monasticon Anglicanum: a history of the abbies and other monasteries, hospitals, frieries, and cathedral and collegiate churches, with their dependencies, in England and Wales, ed. John Caley and others, London 1817-30; TNA=The National Archives, London; WAM= Westminster Abbey Muniments; WCL $=$ Worcester Cathedral Library; $\mathrm{WRO}=$ Worcestershire Record Office (now Worcestershire Archive and Archaeology Service, The Hive)

I would like to thank my son Jamie for his technical skill in preparing the map. 
Liber vitae of Durham Cathedral Priory, are, sadly, the exceptions and not the rule. ${ }^{1}$ However, one type of source which could serve to redress the documentary balance, from the late thirteenth or early fourteenth century onwards, is the ordination lists recorded in episcopal registers. ${ }^{2}$ As both secular and regular clergy were canonically required to be ordained by their diocesan bishop and as, by the later Middle Ages, most monks and canons were expected to become priests, then in theory at least these episcopal ordination lists should preserve the names of all religious clergy in a particular diocese as they passed through the sequence of orders from acolyte to priest. As Virginia Davis has stated, 'Every member of the clergy ought to be included in the ordination lists as he climbed the ranks of the clerical hierarchy.' 3 How complete a record therefore are the surviving ordination lists as evidence for the religious orders? Although they have long been employed by students of monastic history, there has been no attempt to evaluate ordination lists overall, except for individual comments. For example, Robert Swanson has expressed concerns about the 'less certain recording of the ordination lists', stating that they may 'under-record the religious'. ${ }^{4}$ This article aims to offer an assessment of the value of the extant episcopal ordination lists as evidence for monastic prosopography by comparing them with other surviving documents (individual lists of religious communities), with special reference to the houses of monks and regular canons in the diocese of Worcester from about 1300 until the Dissolution.

The twenty monasteries covered in this study were houses of monks and regular canons that lay physically within the bounds of the medieval (pre1540) diocese of Worcester, which essentially, though not exactly, encompassed the counties of Worcestershire and most of Gloucestershire, along with a small part of Warwickshire (see fig. 1). About half of these monasteries were Benedictine: Alcester Abbey (Warws.), Evesham Abbey (Worcs.), St Peter's Abbey Gloucester, Pershore Abbey (Worcs.), Tewkesbury Abbey (Gloucs.), Winchcombe Abbey (Gloucs.) and Worcester Cathedral Priory itself. In addition, the monks of two Benedictine dependent houses, Great Malvern Priory and Little Malvern Priory (both Worcs.),

' John Hatcher, 'Mortality in the fifteenth century: some new evidence', Economic History Review xxxix (1986), 19-38, and John Hatcher, A. J. Piper and David Stone, 'Monastic mortality: Durham Priory, 1395-1529', Economic History Review lix (2006), $667-87$.

2 David Robinson, 'Clerical recruitment in England, 1282-1348', in Nigel Saul (ed.), Fourteenth Century England V, Woodbridge 2008, 53-77 at p. 54; David M. Smith, Guide to bishops' registers of England and Wales: a survey from the Middle Ages to the abolition of episcopacy in 1646 , London 1981 , passim.

3 Virginia Davis, 'Medieval English ordination lists: a London case study', Local Population Studies 1 (1993), 51-6o at p. $5^{1}$.

4 R. N. Swanson, Church and society in late medieval England, Oxford 1989, 83 . 
Religious orders:

- Benedictines

- Augustinian canons

Cistercians

$\square$ Premonstratensians

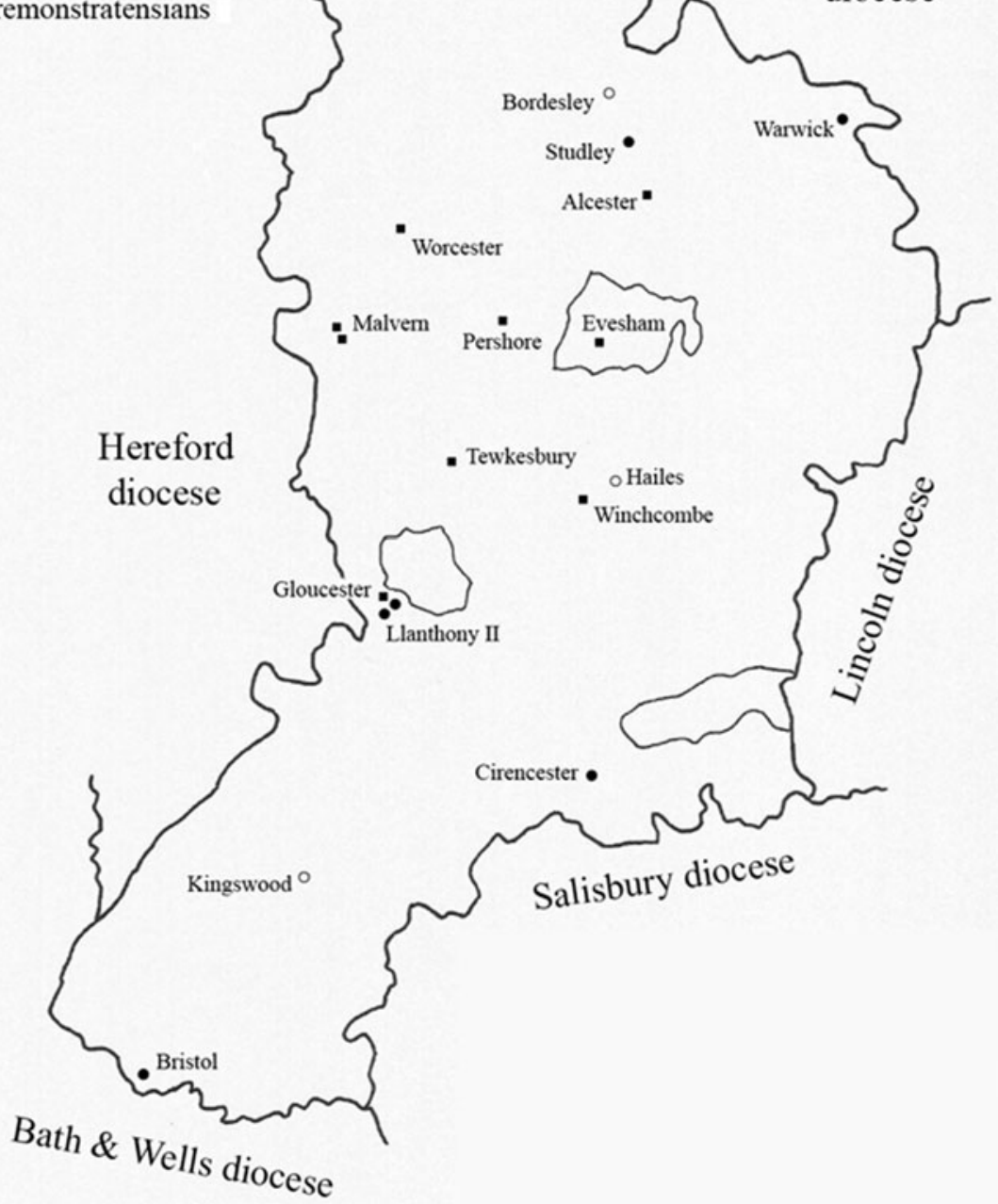

Figure 1. Monasteries in the diocese of Worcester in the late Middle Ages.

appear not infrequently in the ordination lists and so have been included, whereas those of St James Priory Bristol (dependent on Tewkesbury) do not occur in the lists. There were five houses of Augustinian canons in the diocese: St Augustine's Abbey Bristol, Cirencester Abbey (Gloucs.), St Oswald's Priory Gloucester, Llanthony Secunda Priory ('by Gloucester'), 
Studley Priory (Warws.), and St Sepulchre Warwick. However, there might also be added the Hospital of St Mark, Billeswick in Bristol (also known as Gaunt's), whose brethren had adopted the rule of St Augustine, with some modifications, by the early fourteenth century and do appear in the ordination lists of religious clergy. 5 The next largest order represented in the diocese of Worcester were the Cistercians, with three houses: Bordesley Abbey (Worcs.), Hailes Abbey (Gloucs.) and Kingswood Abbey (Gloucs.). Finally, there was also a single house of Premonstratensian canons in the diocese, at Halesowen. A number of other religious houses lay within the diocese of Worcester, such as the Cluniac priory at Dudley and Dodford Priory, but these were either very small and/or dependent cells, and members of their communities are rarely, if ever, found in the ordination lists. Alien priories, such as Astley and Beckford (both Worcs. and both dissolved in 1414), have also been omitted. Two of the religious houses pertinent to this study, Evesham Abbey and St Oswald's Priory Gloucester, technically lay outside the jurisdiction of the bishops of Worcester though physically within the bounds of the diocese. These special situations affected the ordination of the inmates of these two houses differently.

\section{Ordination lists}

Ordination lists, as a category of primary source, have received a certain amount of attention from ecclesiastical historians, often concentrating on a single diocese, though most studies have tended to focus on the ordination of secular clergy rather than their regular counterparts. These lists record the names of clergy when they had been ordained by a bishop to one of the major or holy orders (subdeacon, deacon and priest) and often to the preceding minor order of acolyte. William J. Dohar has suggested that ordination lists originated after 1237 as rosters of probati, that is of prospective ordinands who had been successfully examined or scrutinised prior to ordination according to their moral, physical, legal and educational suitability for clerical life. ${ }^{6}$ The lists are preserved in bishops' registers, usually as independent quires of ordinations that have been sewn into the main register (though some remained separate and were subsequently lost) or, alternatively, as records of individual ceremonies copied into the regular chronological sequence of diocesan business. 7

5 'Hospitals: St Mark, Billeswick, called Gaunt's Hospital', in William Page (ed.), A history of the county of Gloucester, ii, London 1907, $114^{-1} 8$.

6 William J. Dohar, 'Medieval ordination lists: the origins of a record', Archives xx (1992), $17-35$.

7 Ibid. 19; Robinson, 'Clerical recruitment', 53; John A. F. Thomson, Early Tudor Church and society, I485-1529, London 1993, 10. 
Occasionally, ordinations were written on separate folios that were later added to the main register. For most medieval English dioceses the extant ordination lists have been preserved from the last two decades of the thirteenth century or from the first few of the fourteenth. The diocese of Worcester is among the earliest to have records of ordination: the register of bishop Godfrey Giffard contains ordinations from $1282^{8}$ and the subsequent registers continue to record ordinations, with some notable gaps, down to the 1530 .

An announcement of where and when a bishop would hold an ordination ceremony was normally communicated via the diocesan administration in advance, to give candidates sufficient time to prepare for and travel to the event. 9 Ordinations were usually held in churches: the location was not regulated, but depended upon the itinerary of the bishop. ${ }^{10}$ According to canon law, bishops were required to hold ordinations on specific days according to the ecclesiastical calendar, namely on the Saturdays of the four ember-tides: the first Saturday of Lent; the Saturday before Trinity Sunday (May or June); the Saturday after Holy Cross Day (14 September); and that after the Feast of St Lucia (13 December). ${ }^{11}$ If necessary, they could also ordain on two other days during Lent: the Saturday of Passion Sunday (Sitientes) and on Holy Saturday, the day before Easter. Extant registers indicate that most bishops did not hold ordination ceremonies on every ember day of their episcopate. Furthermore, although the bishop himself was required to perform the act of ordination, if he were absent on formal business or otherwise indisposed, he could be replaced by a suffragan bishop. Suffragans were bishops of another diocese, usually holders of nominal or titular sees, notably in partibus

8 Register of bishop Godfrey Giffard, September 23rd, I 268 , to January 26 th, I302, ed. J. W. Willis Bond (Worcestershire Historical Society, 1898).

9 H. S. Bennett, 'Medieval ordination lists in the English episcopal registers', in J. Conway Davies (ed.), Studies presented to Sir Hilary Jenkinson, London 1957, 20-34 at p. 22; Dohar, 'Medieval ordination lists', 20.

${ }^{10}$ Virginia Davis, 'Episcopal ordination lists as a source for clerical mobility in England in the fourteenth century', in N. Rogers (ed.), England in the fourteenth century, Stamford $1993,15^{2-70}$ at pp. $15^{8-9}$.

11 Bennett, 'Medieval ordination lists', 21 ; William J. Dohar, The Black Death and pastoral care: the diocese of Hereford in the fourteenth century, Philadelphia 1995, 17, and 'Medieval ordination lists', 20-1; Robin L. Storey, 'Recruitment of English clergy in the period of the conciliar movement', Annuarium Historiae Conciliorum: Internationale Zeitschrift für Konziliengeschichtsforschung vii (1975), 290-313 at p. 293 n. 7; Robin L. Storey, 'Ordinations of secular priests in early Tudor London', Nottingham Medieval Studies xxxiii (1989), 122-33 at p. 124; Jo Ann Hoeppner Moran, 'Clerical recruitment in the diocese of York, $134^{-}-153^{\circ}$ : data and commentary', this Journal xxxiv (1983), 19-54 at pp. 20-1. 
infidelium. ${ }^{12}$ Canonically, a man should be ordained in his own diocese but he could be ordained in another diocese as long as he had with him a 'dimissorial' or letter dimissory from his bishop indicating that he was free to be admitted to the specified order(s). ${ }^{13}$ Secular and regular ordinands from other dioceses were entered in the ordination lists along with local candidates, though their diocese of origin was added plus a phrase indicating that they had presented the required documentation. Letters dimissory for local ordinands seeking ordination in another diocese might be recorded elsewhere in episcopal registers, and occasionally therefore there is both a record of the letter and the equivalent entry in an ordination list in the register of the other bishop. Over 75 per cent of the ordinations of monks and regular canons examined for this study were performed in the diocese of Worcester; the remainder are recorded in the registers of neighbouring dioceses. Very occasionally, superiors of religious houses might receive a papal indult to ordain their own monks or canons to minor orders (including acolyte), and in the case of exempt houses 'private' ceremonies could in fact be performed by a visiting bishop in the conventual church. ${ }^{14}$

Most surviving ordination lists record the ordination of men to the three holy (major) orders - subdeacon, deacon and priest - and the highest of the non-holy orders, acolyte. Very occasionally, lists of young men receiving first tonsure and exorcists are also recorded. The format of ordination lists can vary. In most Worcester registers, the four orders were usually entered in rising status, starting with acolyte. Secular ordinands are usually distinguished from their less numerous regular counterparts as separate groups in the documents: often the two groups are listed separately, according to order, usually with a specific heading. In other cases the regulars are appended to the list of secular ordinands, and distinguished by the titles frater or dompnus. Occasionally, the secular and regular clergy are not distinguished from one another at all, especially in lists of acolytes and first tonsures, and this makes identification difficult or uncertain. For the vast majority of religious ordinands, the name of the house is stated, sometimes with that of the religious order as well. For those few cases where neither house nor order is supplied, identification becomes problematic. Regular clergy occur in the ordination lists either as individual ordinands or often as part of a group from the same house.

${ }_{12}$ Thomson, Early Tudor Church and society, $111-14$; Swanson, Church and society, 810 ; R. L. Storey, Diocesan administration in fifteenth-century England, York 1972, 6.

${ }^{13}$ David Robinson, 'Ordination of secular clergy in the diocese of Coventry and Lichfield, 1322-1358', Archives xvii (1985), 3-21 at p. 19; Dohar, 'Ordination lists', 18 ; Davis, 'Episcopal ordination lists as a source', ${ }_{154-5}, 15^{8}$ and n. 16.

${ }_{14}$ Martin Heale, The abbots and priors of late medieval and Reformation England, Oxford 2016, 76-7; Swanson, Church and society, 83. 
The age when a man, whether regular or secular, could be ordained to a particular order was restricted canonically. ${ }^{15}$ For acolytes, the minimum age was fourteen years. This was also the minimum legal age for 'admission', that is, when an aspiring male religious was permitted to enter a monastery and start the noviciate. ${ }^{16}$ For the Benedictines and Cistercians, however, the minimum age for admission was eighteen ('to have entered his nineteenth year'). ${ }^{17}$ Admission was probably the point when most (though by no means all) monks and canons ceased using their hereditary family surnames and adopted instead a 'monastic surname', often a toponym indicating place of birth or recent origin. ${ }^{18}$ Furthermore, as the postulant could only be professed after at least one year's probation as a novice, the minimum age of profession was effectively fifteen years, or nineteen for the Black Monks. This would raise the lowest practical age of ordination as acolyte for a professed religious to fifteen. For the major or holy orders, the legal age for subdeacon was seventeen years, for deacon nineteen and for priest twenty-four. Although the days of child oblation were long past, canonical ages were not always adhered to in individual cases. Particularly following the ravages of the Black Death in $1347-8$, there is evidence of various rules for ordination, including the age for the priesthood, being relaxed to boost the recruitment of secular clergy. ${ }^{19}$ Even for the later period the papal archives contain documents relating to regular clergy seeking absolution for past underage profession or ordination, or even formally requesting dispensation to be ordained when underage. ${ }^{20}$ A papal document dated 15 June 1487 names seven Cistercians of Hailes - all ordained between $1475 \times 1483-$ seeking absolution and dispensation because they had been ordained underage and had subsequently celebrated mass. ${ }^{21}$ More seriously, some

${ }^{15}$ Peter D. Clarke, 'New sources for the history of the religious life: the registers of the apostolic penitentiary', Monastic Research Bulletin xi (2005), 1-21 at pp. 6, 18-19; P. H. Cullum, 'Man/boy into clerk/priest: the making of the late medieval clergy', in Nicola F. McDonald and W. M. Ormrod (eds), Rites of passage: cultures of transition in the fourteenth century, New York 2004, $5^{1-65}$ at p. $5^{1}$; Swanson, Church and society, $4^{0 .}$

${ }^{16}$ F. Donald Logan, Runaway religious in medieval England, c. I $240-1540$, Cambridge 1996, 12; Richard Copsey, 'Initiation: Christian perspectives', in William M. Johnston (ed.), Encyclopedia of monasticism, Chicago-London 2000, 646-8 at p. 647 .

${ }^{17}$ Joan Greatrex, The English Benedictine cathedral priories: rule and practice, c. I2701420 , Oxford 2011,53 , and 'Prosopography of English Benedictine cathedral chapters: some monastic curricula vitae, Medieval Prosopography xvi (1995), 1-26 at p. 7. See also David Knowles, The monastic order in England: a history of its development from the times of St Dunstan to the Fourth Lateran Council, 940-1 2 I6, Cambridge 1963, 634 n. 1.

${ }_{18}$ David Knowles, The religious orders in England, Cambridge, 1948-59, ii. 231.

19 Moran, 'Clerical recruitment', 26-7; Copsey, 'Initiation', 647.

${ }^{20}$ Logan, Runaway religious, 12-16; Supplications from England and Wales in the registers of the Apostolic Penitentiary, $\mathrm{I}_{4} \mathrm{IO}^{-} \mathrm{I}_{5} \mathrm{O}$, ed. Peter D. Clarke and Patrick N. R. Zutshi, Woodbridge $2013^{-1} 5$, i, p. xl. 
individuals were professed and ordained below the canonical ages under coercion: ${ }^{22}$ in 1443 William Leighton, monk of Bordesley, appealed to the pope on the grounds that "when he was less than fourteen years old he was induced by the bland and deceptive words of some of the monks'. ${ }^{23}$ Similar claims were especially frequent in the late $1530{ }^{2}{ }^{24}$ Such notable exceptions aside, it may be assumed that the majority of regular ordinands in the diocese of Worcester between about 1300 and the Dissolution were young men in their late teens or early twenties.

For the purposes of this study a total of 6,777 ordination events for the period from about 1300 to about 1540 were collected from the registers of the bishops of Worcester as well as from those of neighbouring English dioceses. The term 'ordination event' here refers to the ordination of an individual religious to one of the holy orders (minor or major): in those cases where an individual was ordained to more than one order, usually acolyte and subdeacon, at a single ordination ceremony held on one day, this is treated in the statistics cited as two 'events' rather than one. Of the 6,777 attested ordination events, about 77.5 per cent $\left(n=5,25^{1}\right)$ occur in the registers of the bishops of Worcester. Most of the remaining ordinations can be found in Hereford diocesan registers $(1,100=16$ per cent of the total), with a small number found in the registers of the other four dioceses: Coventry and Lichfield $(262=4$ per cent $)$, Bath and Wells $(114=1.7$ per cent), Salisbury $(23=0.3$ per cent $)$ and Lincoln $(22=0.3$ per cent $)$. Of these dioceses, the Hereford registers record relevant ordinations for the whole period covered by this study, although with some gaps; the Lichfield registers also cover both the fourteenth and fifteenth centuries; Bath and Wells, the fifteenth and early sixteenth; and the handful of Salisbury ordinations all date from the fifteenth century.

The numbers of ordinations of regulars from the religious houses pertinent to this study during the period 1301 to 1535 have been calculated according to five-year groupings $(1301-5,1306-10$ through to $1531-5)$ (see fig. 2). Although there is significant fluctuation over time, with fiveyear periods of high ordination being succeeded by periods with few ordination events, there is an evident increase during the first half of the fourteenth century and a distinct decrease during the 153 os. For the latter period, the evidence in the various diocesan registers for the ordination of religious tends to peter out after ${ }^{1533-4}$ such that the final block $\left(153^{1-5}\right)$ shows a marked decline.

${ }^{22}$ Logan, Runaway religious, 18-19; Supplications, i, p. xl.

23 Calendar of papal registers relating to Great Britain and Ireland, ed. W. H. Bliss and others, London 1893-, ix. 335. For his ordination see The register of the diocese of Worcester during the vacancy of the see, usually called 'Registrum sede vacante', ed. J. W. Willis Bund (Worcestershire Historical Society, 1893-7), 393-4, 402; WRO, b7o6.093-BA2648/5(iii), p. 189.

${ }_{24}$ For example, $L P$ vii. 1367 . 


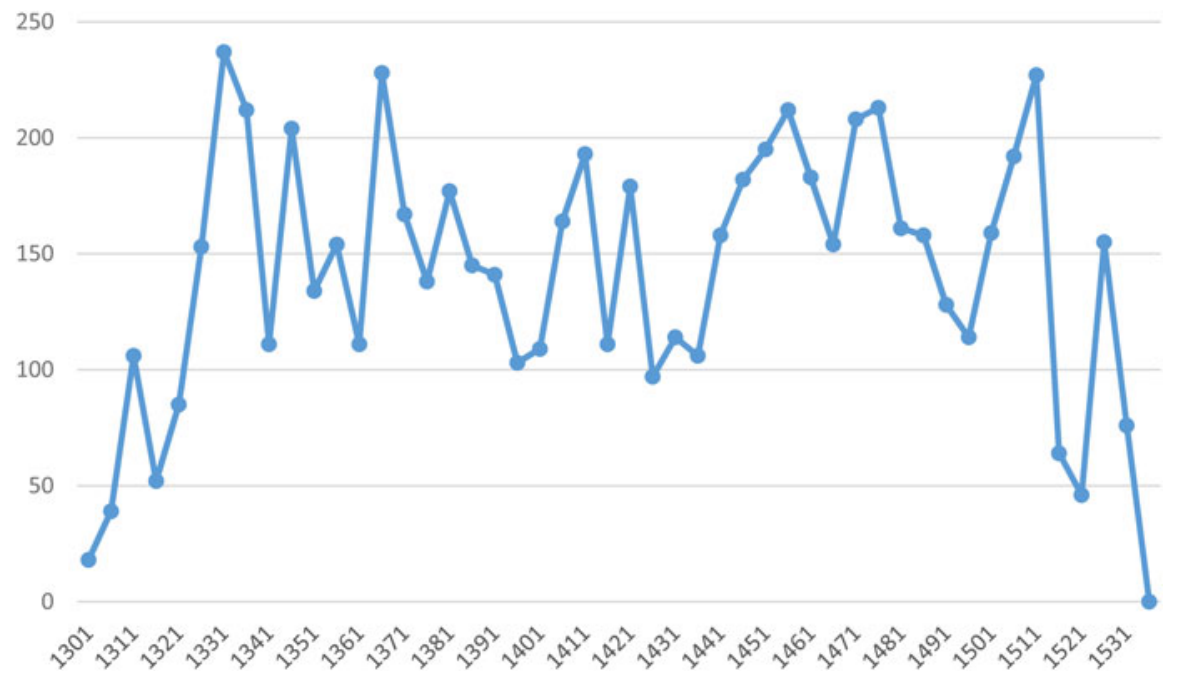

Figure 2. Ordinations of Worcester diocese religious clergy over time, $1301-5$, 15 o6-10 etc.

\section{Ordination and conventual lists compared}

To determine the completeness of the ordination lists as a record of monastic prosopography, they have been compared with what may be termed 'conventual lists', that is, lists of the names of the inmates of a monastery (the convent) drawn up at a particular time, often on a specific day. If the surviving ordination lists are more or less complete, they would be expected to record the ordination of all the individuals named in a contemporary conventual list. The ${ }_{17} 8$ such lists consulted for this study (see appendix 1) were compiled on the occasion of various types of event: the election of a new superior; visitation of the religious house; the taxation of the clergy; and the events associated with the dissolution of the monasteries. About half of the conventual lists fall into the last category, including twenty lists of ex-monastic pensions dating from the 155 os. Inevitably, the number of conventual lists varies significantly over the twenty religious houses examined. The smaller houses are represented by fewer lists than their larger, wealthier counterparts. Most of the larger houses are well represented, with the notable exception of Evesham Abbey. Furthermore, it is evident that not all conventual lists are necessarily complete records of their respective religious communities, notably those from the Dissolution and $155^{\text {os. }}$

Appendix 1 summarises the results of the attempts to identify monks and canons named in the conventual lists as ordinands in the ordination lists from Worcester and neighbouring dioceses. Ordered by religious house, 
it indicates how many monks or canons are named in each list, together with how many it has been possible to identify in the ordination lists. Superiors (abbots and priors) are counted separately because it was not uncommon for heads of houses to be external appointees. The percentages of regulars in each conventual list identified in the ordination lists vary significantly. Only for eight of the 178 conventual lists can all the monks or canons named be identified at least once in the ordination lists from Worcester and neighbouring dioceses. ${ }^{25}$ At the other extreme, in a handful of instances hardly any of the religious in the relevant conventual lists are recorded being ordained: for example, only two canons of St Augustine's Bristol named in the conventual list drawn up for the abbatial election of $135^{2} / 3$ can be identified in the ordination lists. It is perhaps significant that the majority of conventual lists for which only $5^{\circ}$ per cent or fewer of the men named therein can be found in the ordination lists date either from the first half of the fourteenth century or from the period of the Dissolution $\left(1536 \times 154^{0}\right)$. Indeed, what is evident is low average percentages for the first half of the fourteenth century; a gradual, if uneven, increase thereafter; relatively steady averages from the mid-fifteenth to early sixteenth; and finally a clear decline in the 1530 ( see fig. 3). ${ }^{26}$ This last decade was assessed as two units $(1530-5$ and $1536-40$ ) because of the somewhat problematic nature of the data retrieved from documents of the Dissolution.

Taken as a whole, the average for all religious houses ${ }^{27}$ comes out as around 73.5 per cent, a figure which can be taken as an answer to the question posed in the title of this paper. In theory, the ordination lists should preserve a complete record of passage of regular ordinands through the successive orders. This, however, was clearly not the case for about a quarter of the monastic clergy in the diocese of Worcester between 1300 and $154^{\circ}$.

\section{Structural gaps in ordination lists}

One factor which may explain these statistics is the preservation of the extant episcopal ordination lists. The chronological distribution of

\footnotetext{
25 Bristol, St Augustine's (1491-2); Bristol, St Mark's (1498); Gloucester, St Oswald's (1537); Halesowen Abbey (1475); Llanthony Secunda Priory (1407); Warwick, St Sepulchre's (1534); and Winchcombe Abbey (1395).

${ }^{26}$ Here percentages for all the conventual lists from the same decade have been divided by the number of lists. For example, for the first decade of the fourteenth century there is only one list, associated with an abbatial election at Cirencester Abbey (1307), so the total of $17 \%$ for that single conventual list is also the total for that decade ('1 1300 ').

${ }^{27}$ The sum of all percentages divided by the number of lists with percentages.
} 


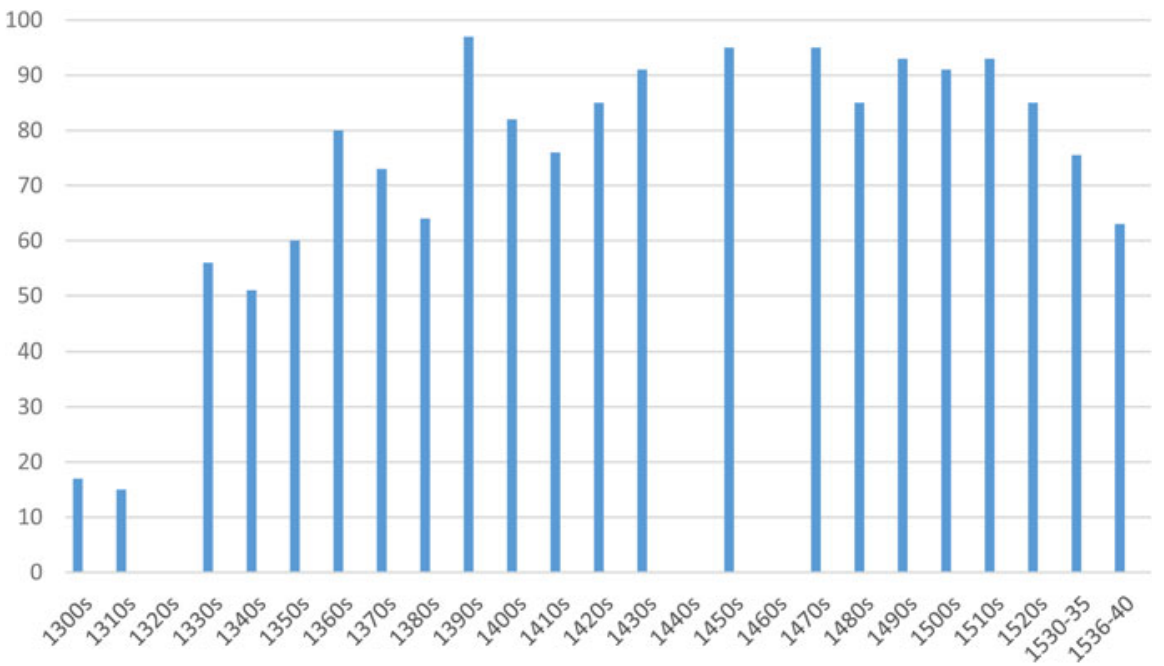

Figure 3. Percentage of religious clergy in conventual lists identified in ordination lists, by decade.

surviving ordinations of regular clergy and reveals a clear rise in the number of recorded ordination events during the first half of the fourteenth century, a significantly fluctuating pattern thereafter (though never going below 100 ordination events in any given five-year block), and finally a marked decline in recorded ordinations in the sixteenth century, especially during the 153 os (see fig. 2). This pattern is not too dissimilar to that represented in fig. 3 for the percentage of monks and canons in the conventual lists who can be identified in the ordination lists. Such a correspondence may suggest that the chronological distribution of ordinations is not merely a product of patterns of recruitment, but reflects the survival rate of ordination records, especially for the early and later stages of this period. Indeed, that regulars were still being ordained right up until the eve of the Dissolution may be deduced from the fact that, on 19 May 1538, Thomas Walcott, monk of Pershore Abbey, was granted a dispensation to be ordained deacon and priest 'within the prohibited times' and both on the same day, though no record of this ordination survives. ${ }^{28}$ Similar evidence can also be found for other regulars who, from the testimony of the registers, were first ordained during the early 1530 os but had evidently been ordained further by $1537-8$, although there is no record in the registers. ${ }^{29}$ This

${ }^{28}$ FOR, 133. See also WRO, b7o6.o93-BA2648/9(i), p. 1 7; TNA, E25/102/26; DKR vii, appendix ii, p. 298.

29 For example, John Anthony, monk of Winchcombe, ordained deacon in 1532 , and termed priest in 1537; and Maurice Berkeley, canon of Llanthony, ordained 
conclusion is supported by the fact that for some other dioceses there is evidence of the continued ordination of religious clergy until the Dissolution, though in decreasing numbers. $3^{\circ}$

In addition to the evident poor survival of ordination records for the first half of the fourteenth century and for the 1530 s, the significant fluctuation in the numbers of ordination events in the later fourteenth and the fifteen centuries may also reflect structural gaps within the ordination record extant in the registers. Would it have been possible for a religious to have moved through the successive orders from acolyte to priest during the period covered by a gap and therefore to have slipped through the documentary net? This possibility would depend both on the size and frequency of such gaps, and also on how long it would take to move up through the orders. Analysis of the extant ordination lists from the registers of the bishops of Worcester indicates that there are a number of significant gaps in the record. Many, but by no means all, of these gaps correspond to periods of vacancy between bishops and can be supplemented using the so-called Sede vacante register. ${ }^{31}$ Table 1 displays the extant ordinations recorded in the registers of the bishops of Worcester, including the Sede vacante register, from the mid-fourteenth century to the 153 os. The date ranges of ordinations (for example, 'Dec. 1407-June 1417') do not necessarily indicate that ordination ceremonies were celebrated on every possible ember day during the period in question, but rather that there is evidence of ordinations being held on most possible canonical days during that time. Where there are larger gaps in the record these are indicated.

Most of the larger gaps in the Worcester registers' ordinations correspond to notable low points in the chronological distribution of ordinations of Worcester diocese religious clergy overall (see fig. 2). For example, there was a low rate of ordination for the consecutive five-year blocks 1396-1400 and $1401-5$, and table 1 demonstrates that between the last extant ordination ceremony held by Bishop Tideman de Winchcombe (December 1397) and the first recorded one of his successor Clifford (December 1401 ) there is a gap of four years, with a single ceremony being recorded in the Sede vacante register for 24 September 1401 . Winchcombe did not die until 13 June 1401, so the last few years of his episcopate are poorly served by the surviving ordination lists. For 1397 there are thirty-one ordinations recorded for members of the religious houses pertinent to this study.

subdeacon in 1532, and had become deacon by 1538 : WRO, b7o6.o93-BA2648/9(i), pp. 166, 172-3; FOR, 116; DKR viii, appendix ii, p. 25 .

$3^{\circ}$ Thus, John Mapilton was ordained priest as monk of Meaux (Yorks.) on 20 September 1539, less than three months before Meaux Abbey was surrendered (11 December): Borthwick Institute, York, register 28 (Lee), fo. 198r; LP xiv/ 2, 670.

$3^{1}$ WCL, reg. A.1, edited and calendared in Registrum sede vacante. 
Table I. Dates of ordination lists in Worcester registers, $135^{\circ}-154^{\circ}$

\begin{tabular}{|c|c|c|}
\hline Register & Bishop & Ordination dates \\
\hline b7o6.o93-BA2648/3(ii) & Thoresby $\left(135^{\mathrm{O}-2}\right)$ & Feb. $135^{\circ}-$ Mar. $135^{2}$ \\
\hline b7o6.o93-BA2648/3(iii) & Brian $(1353-61)$ & Dec. $1353-$ Sept. 1361 \\
\hline b7o6.o93-BA2648/4(i) & Barnet $\left(13^{62-3}\right)$ & $\begin{array}{l}\text { June-Dec. } 13^{62} \\
\text { GAP }\end{array}$ \\
\hline b7o6.o93-BA2648/4(ii) & Whittlesey (1364-8) & June $1365-$ Sept. 1368 \\
\hline b7o6.o93-BA2648/4(iii) & Lenn $(1369-73)$ & $\begin{array}{l}\text { Sept. } 1369-\text { Sept. } \\
1372\end{array}$ \\
\hline Reg. sede vac. & & Mar. 1373 \\
\hline Reg. sede vac. & & Mar.- June 1375 \\
\hline b706.093-BA2648/4(iv) & Wakefield $\left(1375^{-95}\right)$ & Sept. 1377-Mar. 1394 \\
\hline Reg. sede vac. & & Apr. 1395 \\
\hline b706.093-BA2648/4(v) & Winchcombe $\left(1395^{-1401}\right)$ & $\begin{array}{l}\text { Sept. } 1395^{-D e c . ~} 1397 \\
\text { GAP }\end{array}$ \\
\hline Reg. sede vac. & & Sept. 1401 \\
\hline b7o6.093-BA2648/5(i) & Clifford $(1401-7)$ & Dec. $1401-$ Sept. 1407 \\
\hline b706.093-BA2648/5(ii) & Peverel $(1407-19)$ & Dec. 1407-June 1417 \\
\hline Reg. sede. vac. & & Apr.- June $14^{19}$ \\
\hline b706.093-BA2648/5(iii) & Morgan $\left(14^{1} 9^{-26}\right)$ & Mar. 1420-Mar. 1426 \\
\hline b706.093-BA2648/5(iv) & Polton $(1426-33)$ & Dec. 1426 -Sept. 1433 \\
\hline Reg. sede vac. & & Dec. $1433-$ Dec. 1434 \\
\hline b7o6.093-BA2648/6(i) & Bourgchier $\left(1435^{-43}\right)$ & May 1435-Jan. 1444 \\
\hline b706.o93-BA2648/6(ii) & Carpenter $\left(1444^{-76}\right)$ & Dec. $1444^{-M a r . ~} 147^{1}$ \\
\hline b706.o93-BA2648/6(iii) & Carpenter & Sept. 1471 -June 1476 \\
\hline b7o6.o93-BA2648/7(i) & Alcock $(1476-86)$ & $\begin{array}{l}\text { Apr. } 1477 \text {-Sept. } 1483 \\
\text { GAP }\end{array}$ \\
\hline b7o6.o93-BA2648/7(ii) & Morton $\left(14^{87}-97\right)$ and others. & $\begin{array}{l}\text { Apr. 1487-May } 1494 \\
\text { GAP }\end{array}$ \\
\hline b7o6.o93-BA2648/7(iii) & G. de' Gigli ( $1497-8)$ & Apr.- June 1498 \\
\hline \multirow[t]{2}{*}{ b7o6.o93-BA2648/8(i) } & $\begin{array}{l}\text { S. de' Gigli }\left(1499^{-1} 5^{21}\right) \text { and } \\
\text { others }\end{array}$ & May $1499-$ Mar. $15^{17}$ \\
\hline & & GAP \\
\hline b7o6.o93-BA2648/9(i) & Ghinucci $\left(15^{22-35}\right)$ & $\begin{array}{l}\text { Dec. } 1520 \\
\text { GAP }\end{array}$ \\
\hline b7o6.o93-BA2648/9(i) & Ghinucci & $\begin{array}{l}\text { Mar.-May } 1523 \\
\text { GAP }\end{array}$ \\
\hline b7o6.o93-BA2648/9(i) & Ghinucci & Sept. $15^{26}$-Mar. $15^{27}$ \\
\hline b706.093-BA2648/7(ii) & Ghinucci and others & Mar. $15^{27}$-Sept. 1533 \\
\hline b7o6.o93-BA2648/8(ii) & Latimer $\left(1535^{-9}\right)$ and others & [no ordinations] \\
\hline b7o6.o93-BA2648/9(iii) & Bell (1539-43) & $\begin{array}{l}\text { Dec. } 1540-A p r .154^{1} \\
\text { [post-Dissolution] }\end{array}$ \\
\hline
\end{tabular}

However, this falls to a mere four in 1398, none for 1399 and eight in 1400 , all of which are recorded in the register of Bishop Trefnant of Hereford. For 1401 the number creeps up to twelve, with most recorded in the Sede vacante register and a handful in the register of Bishop Burghill of 
Lichfield. $3^{2}$ There are no ordinations of regulars for 1402 but, for 1403 , the number leaps to thirty-one. Although Clifford had been elected bishop of Worcester in the summer of 1401, he did not visit his new diocese until January 1403. Thus, the earliest ordination ceremonies of his episcopate took place at London and Hillingdon (December 1401December 1402) and, although some secular ordinands from Worcester diocese did travel to these, the first regulars of his diocese to be ordained by him had to wait until the ceremony held on 10 March 1403 at Llanthony by Gloucester. 33 There are letters dimissory for one monk of Worcester and four canons of Llanthony in Clifford's register, dated June and July 1402 respectively, but so far it has proved impossible to trace any record of the ordination of these men by other bishops.

The last phase of the medieval diocese of Worcester, before the reforming bishop Hugh Latimer, was distinguished by the episcopates of four nonresident Italian bishops: episcopal registers survive for Giovanni de' Gigli (1497-8), Silvestro de' Gigli $\left(149^{8-1521)}\right.$ and Girolamo Ghinucci (1522-35), but not for the brief episcopate of Cardinal Guilio de' Medici $\left(15^{2} 1-2\right)$; and these documents indicate that, despite the permanent absence of the bishops, it was more or less business as usual in the diocese, with ordinations undertaken by suffragan bishops. ${ }^{44}$ However, the sequence of ordinations recorded in the registers for the thirty-eight years between the death of Bishop Robert Morton (May 1497) and the resignation of Bishop Ghinucci (May 1535) do contain a number of significant gaps which amount to the equivalent of about eleven years, or almost 30 per cent of the time period covered (see table 1). This is compounded by the lack of ordinations for the last three years of Morton's episcopate (May 1494-May 1497). Thus, during the years $15^{18-22}$ inclusive, there is a record of only eight ordinations of monks or regular canons from the diocese of Worcester, and these are all recorded in the registers of other dioceses.

Since many of the low points in the ordination records for religious clergy in the diocese of Worcester correspond to gaps in the surviving registers, is it possible that some of those monks and canons, named in the conventual lists but for whom no ordinations survive, could have been ordained acolyte, deacon, subdeacon and priest during one of these gaps? As most extant ordination lists relevant to this study record ordinations not only for the three major orders but also for acolyte as well,

$3^{2}$ Lichfield Record Office, B/A/1/7, fo. $218 \mathrm{v}$.

33 The register of Richard Clifford, bishop of Worcester, I4OI-I 407: a calendar, ed. Waldo E. L. Smith, Toronto $1976,67-78$.

34 Kevin Down, 'The administration of the diocese of Worcester under the Italian bishops, 1497-1535', Midland History xx (1995), 1-20. See also Mandell Creighton, Historical essays and reviews, London 1902, 202-34. 
then it should be possible to determine how long, on average, monks and canons took to progress from acolyte to priest. Canon law prescribed the minimum age for ordination to particular orders, and this, along with prohibitions against receiving certain successive orders at the same ceremony, would in theory have limited how quickly clerics could move up the sequence. For example, a secular cleric ordained acolyte at the minimum age of fourteen would have had to wait ten years until he could become a priest. However, from about $135^{\circ}$ onwards, following the need to encourage clerical recruitment after the demographic ravages of the Black Death, studies have shown that dispensations and practical considerations meant that many secular ordinands might pass through the orders within two or three years or even more quickly.35 Was this also the case for religious clergy from the diocese of Worcester?

For those monks and canons for whom records of ordination as both acolyte and priest survive $(n=698)$, the vast majority became priests within three years or less of being ordained acolyte (see fig. 4). A small number $(\mathrm{n}=22)$ would appear to have been ordained acolyte and priest within a single year. For example, on 12 March 1440, four canons of St Oswald's Priory Gloucester - Richard Cheltenham, John Hemming, Robert Morris (Morys) and John Malvern - were ordained acolyte by Bishop Spofford of Hereford, and all progressed to subdeacon two weeks later on 26 March. The same four canons can be found ordained deacon on 21 May 1440 in the register of Bishop Stafford of Bath and Wells; and Richard Cheltenham and John Hemming's ordination as priest occurs in the same register, dated 24 September 1440, though their two confrères had to wait until $1442.3^{6} \mathrm{~A}$ few more regulars were ordained priest in the year following their ordination as acolyte, but most (over 40 per cent) moved through the successive orders and became priest two or three years after being ordained acolyte. The rate begins to drop off thereafter, though a few individuals seem to have taken a considerably longer time to become priest, in some cases over six years. For instance, of the five canons of Llanthony by Gloucester ordained acolyte on 10 June $15^{14}$, Gerard Aylburton did not become a priest until

35 Swanson, Church and society, 42-3; Moran, 'Clerical recruitment', 26, 29. See also Robinson, 'Ordinations of secular clergy', 7.

$3^{6}$ Registrum Thome Spofford, episcopi Herefordensis, A.D. MCCCCXXII-MCCCCXLVIII, ed. Arthur Thomas Bannister (Canterbury and York Society, 1919), 333-4, 339; The register of John Stafford, bishop of Bath and Wells, I425-I443, ed. Thomas Scott Holmes (Somerset Record Society, $19^{1} 5^{-16}$ ), 383, 387. Over half the religious who appear to have progressed through the orders in less than a year were members of smaller houses and it is likely that the relatively small size of these communities necessitated speedier ordination in order to fulfil the relevant duties of a deceased priest. 


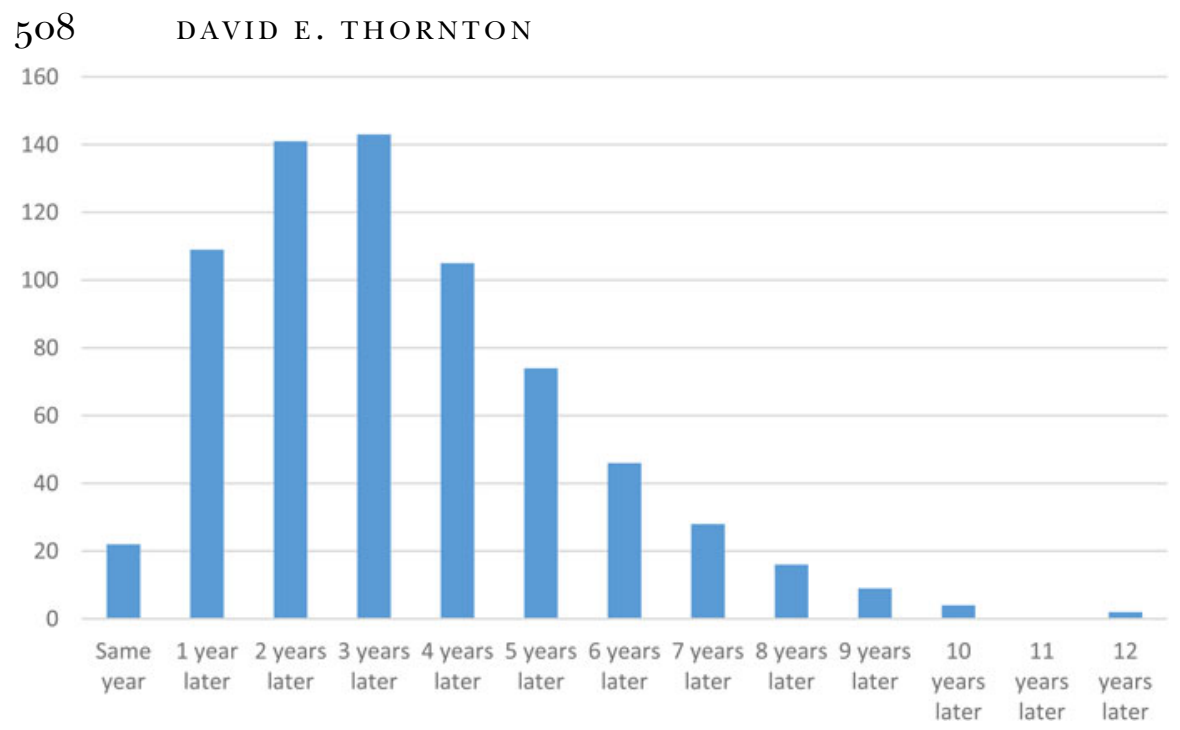

Figure 4. Time span between ordination as acolyte and priest.

1523 and William Worcester had to wait until 26 May 1526.37 Despite such exceptions, almost two-thirds of the 698 regulars whose ordinations as both acolyte and priest are recorded did so in less than four years. The mean number of years between ordination as acolyte and priest was 3.37. This figure would suggest that many religious could in theory have undergone ordination from acolyte to priest during one of the $3^{+-y e a r}$ gaps in the registers, only to first appear in the documentation as a name in a conventual list.

A closer comparison of the ordination and conventual lists may serve to further clarify the likelihood of 'missing' ordinands due to periods of poor record survival. The order of names in conventual lists often indicates relative seniority, which in this context means years since admission or profession: the first monks or canons to be named were usually the superior and other obedientiaries who had joined the community - and had therefore been ordained - earliest in time, and the last named were those brethren most recently admitted, often still undergoing ordination. Thus, by plotting the known ordination dates of the regulars named in a conventual list, it can be seen that those who occur at the beginning of the list had been ordained earlier than those who occur later in the list. By way of illustration, if the names of monks of St Peter's Gloucester as listed in order in the poll

37 WRO, b7o6.o93-BA2648/8(i), pp. 322, 330; Registrum Caroli Bothe, episcopi Herefordensis, A.D. MDXVI-MDXXXV, ed. A. T. Bannister (Canterbury and York Society xxviii, $\left.19^{21}\right), 3^{1} 5,33^{2}$. 
tax return for $1379^{38}$ are set against their known dates of ordination (see table 2) it can be seen that the first monks in the tax list would have been ordained in about $135^{\circ}$. The dates continue more or less chronologically, with one notable gap, down to the early 138 os for the last named individuals. For a number of these monks, letters dimissory are preserved in the Sede vacante register.

In such cases, where seniority clearly underlies the order of names, it is therefore possible to estimate the ordination date ranges for those monks or canons who are mentioned in a conventual list but are not named in the extant ordination lists. Thus, the return for St Peter's Gloucester names thirty-six monks (plus the abbot), of whom seven do not appear in the extant ordination lists, although one, William Britt, does occur in a letter dimissory. ${ }^{39}$ Four of them occur near the start of the list and are given in an uninterrupted sequence: William Upton, Peter Upton, Alan Aylburton, Walter Frocester. The monks named immediately before this sequence were ordained around $135^{\circ}$, while those occurring after this sequence occur in the ordination lists in the later 1360 . This may suggests that the four monks in question would have been ordained during the $\mathrm{mid} /$ late 135 os or early '6os.

Furthermore, many returns for the same poll tax name other monks and canons whose ordinations are not recorded in the surviving registers and who, judging from their relative positions in the tax lists, were probably also ordained during the 135 os or early ' 60 , like the four monks of Gloucester. Thus, four Cistercians of Kingswood do not appear in the ordination lists, and of these two - Thomas Hay and Edward de Bristol are preceded in the return by monks whose recorded ordinations are dated $135^{\circ} \times 135^{2}$, and followed by another ordained in $1365^{4^{\circ}}$ The return for Great Malvern Priory contains two names, also located near the beginning of the list - John de Ross (third place) and Richard Worcester (fifth) - who are not found in the ordination lists: the ordination dates of the surrounding monks in the return suggest that they may have been ordained in the $135^{\text {os. }} .^{1}$ The returns for other houses also point to the early $135^{\circ}$ s (Hailes and Tewkesbury), the $135^{\circ}$ (Pershore) or the early 1360 (Winchcombe) as the probable dates of ordination for monks missing from the surviving ordination lists. The early $135^{\circ}$ and especially early '6os witnessed declines in the number of extant annual ordinations recorded in the Worcester registers, corresponding to a gap between ordinations celebrated by Bishops Thoresby and Brian (twenty-one months) and a larger one between those by Bishops Barnet and Whittlesey (thirty months) (see fig. 2).

$3^{8}$ TNA, E1 $79 / 58 / 5$.

40 TNA, E1 $79 / 58 / 5$.
39 These names are italicised in the table. $4^{1}$ TNA, E $179 / 5^{8 / 11}$. 
Table 2. Monks of Gloucester in 1379 and ordination dates

\begin{tabular}{|c|c|c|c|c|c|}
\hline & Name & Acolyte & Subdeacon & Deacon & Priest \\
\hline 01 & John [de Boyfield], abbot & & & & 1353 \\
\hline 02 & $\begin{array}{l}\text { Everard [de Hereford], } \\
\text { prior }\end{array}$ & & $135^{1}$ & $135^{1}$ & \\
\hline o3 & John Hulle & $1337(?) *$ & & & \\
\hline $\mathrm{O} 4$ & William Rodley & & & & $135^{\circ}$ \\
\hline 05 & John Frampton & & $135^{1}$ & $135^{1}$ & 1353 \\
\hline o6 & William Upton & & & & \\
\hline 07 & Peter Upton & & & & \\
\hline 08 & Alan Aylburton & & & & \\
\hline o9 & Walter Frocester & & & & \\
\hline 10 & John de Bristol & & 1365 & 1366 & \\
\hline 11 & John Ross & & 1365 & 1366 & \\
\hline 12 & Edmund Dursley & 1368 & 1369 & & \\
\hline 13 & John Stonehouse & & & & \\
\hline 14 & William Lydney & 1370 & & & \\
\hline 15 & Nicholas Dene & & & 1372 & \\
\hline 16 & John Overton & & 1370 & 1372 & \\
\hline 17 & Thomas Cam & 1372 & 1372 & & \\
\hline 18 & William Ludlow & & 1371 & & \\
\hline 19 & Roger Shell & 1372 & & & $\left(1374\left[=\mathrm{ld}^{\dagger}\right]\right)$ \\
\hline 20 & Roger Appleby & 1372 & 1372 & & $(1374[=\mathrm{ld}])$ \\
\hline 21 & William Aston & 1372 & 1372 & & 1374 \\
\hline 22 & John Upton & 1372 & 1372 & & $(1374[=\mathrm{ld}])$ \\
\hline 23 & Robert Badminton & $\begin{array}{l}(1374 \\
[=1 d])\end{array}$ & 1375 & 1375 & 1377 \\
\hline 24 & William Brit & & & & $(1374[=\mathrm{ld}])$ \\
\hline 25 & Hugh Morton & & 1374 & & 1377 \\
\hline 26 & John Stratford & 1372 & & & \\
\hline 27 & John (Mor?)ton (Milton?) & 1377 & & 1378 & \\
\hline 28 & John Stapleton & 1377 & & 1378 & $13^{80}$ \\
\hline 29 & Thomas Hereford & & 1379 & & \\
\hline 30 & Robert Clifton & 1379 & 1379 & & \\
\hline 31 & Thomas Maisemore & 1379 & 1379 & & \\
\hline 32 & Walter Westhale & 1379 & 1379 & & \\
\hline 33 & William Fawkoner & & & & \\
\hline 34 & Thomas Nibley & $\begin{array}{c}1379 / \\
80^{4}\end{array}$ & $13^{80 / 1}$ & 1382 & 1383 \\
\hline 35 & John Hartpury & $1379 / 80$ & $1380 / 1$ & $13^{82}$ & $13^{8} 3$ \\
\hline 36 & John Gloucester & $1379 / 80$ & $1380 / 1$ & 1382 & \\
\hline 37 & John Nibley & $1379 / 80$ & $1380 / 1$ & 1382 & \\
\hline
\end{tabular}

* This may be the John de Hulle ordained acolyte in 1337 and subalmoner in 1348 , or a later namesake: Registrum Thome de Charlton, episcopi Herefordensis, A.D. MCCCXXVIIMCCCXLIV, ed. W. W. Capes (Canterbury and York Society ix, 1913), 172; Roy Martin Haines, A calendar of the register of Wolstan de Bransford, bishop of Worcester, 133949 (Worcestershire Historical Society n.s. iv, 1966), 168.

${ }^{\dagger} \mathrm{ld}=$ letter dimissory.

$\$$ The exact date of the relevant ordination ceremonies is not clear in the registers. 
A similar pattern can be discerned when the conventual lists drawn up as part of Archbishop Morton's visitation of the diocese of Worcester in 1498 are examined. $4^{2}$ As for 1379 , the order of names in these lists appears to reflect seniority and, again, there are individual or, in some cases, consecutive sequences of regulars who cannot be traced in the extant ordination lists but who, judging from the known ordination dates of proximate names, were ordained contemporaneously. In this case, the monks or canons in question are generally found towards the end of their respective lists, though usually not as the very last names, and were probably ordained during the mid- to late 149 os. For example, to begin again with St Peter's Gloucester, the list in Morton's register contains an unbroken sequence of five monks - Richard Ledbury, John Poole, Walter Tutbury, William Thornbury and John Cirencester (Cisceter) - who do not occur in the ordination lists. 43 The preceding monks in the list were all ordained between 1489 and 1494, and those that follow received ordination after 15 oo. This would suggest the date range $1495^{-1} 5^{\text {oo }}$ for the five monks of Gloucester. Other lists in Morton's register contain sequences of names, all located towards the end of the conventual lists, that cannot be found in the ordination lists: for example, five monks of Pershore (probably ordained 1494-9); three canons of Cirencester (1490-8); and three monks of Tewkesbury $(1496-9)$. There was a four-year gap in the ordination record between the last recorded ceremony celebrated by Bishop Morton (May 1494) and the handful of ordinations celebrated during the short pontificate of Giovanni de' Gigli (April and May 1498) (see table 1), which corresponds to the low general ordination rates for the $5^{-}$ year blocks $1491-5$ and 1496-150o (see fig. 2). In addition, the 1498 conventual lists contain other names missing from the ordination lists that do not conform to this pattern. The list for Llanthony Priory includes the infirmarer William de Awre, for whom no ordination record has been found: he is preceded by canons ordained in $1477 \times 80$ and $1480-1$, and is succeeded by others ordained in 1488 and $1488 \times 90.44$ We can therefore estimate that Brother William had been ordained at some time during the 148 os, probably during the 'gap' in the surviving ordination records in the mid-1480s (see table 1). Other conventual lists may also reflect a similar ordering of names, and thereby help in estimating the ordination dates of monks or canons missing from the extant ordination lists.

The evidence of both the poll tax returns for 1379 and of Morton's visitation in 1498 would suggest that in many cases where monks and canons are not recorded in the ordination lists, the explanation may be due to gaps in the extant episcopal registers. For 1498 there are 262 individuals

$4^{2}$ The register of John Morton, archbishop of Canterbury, I486-I5oo, ed. Christopher Harper-Bill (Canterbury and York Society, 1987-200o), ii. 128-33.

43 Ibid. ii. 129.

44 Ibid. ii. 130. 
explicitly named in the relevant visitation lists, of whom thirty-two cannot be found in the ordination lists. Of the latter about 65 per cent may have been undergoing ordination more or less at times when there are now gaps in the extant Worcester registers: eighteen during the 1494-8 gap, and a possible further three during the gap in the early 1480 . For 1379 the numbers are more difficult to determine, due to legibility problems in the returns, but there are at least 266 names, of which about thirty-eight have no equivalents in the ordination lists. Of these latter, at least seventeen (45 per cent) were probably ordained during the $135 \mathrm{os}$. If these rough figures are extrapolated, then it may be postulated that at least $5^{\mathrm{o}-60}$ per cent of the 'missing' ordination events for the period 1300-1540 may have been lost due to gaps in the surviving episcopal registers. However, this may not be true for all the religious for whom ordination records are no longer extant. In these cases, different reasons for their absence should be sought.

\section{Discussion}

Just under 25 per cent of the ordination events collected for this study are recorded in episcopal registers of dioceses that shared a boundary with that of Worcester, notably Hereford. For the most part, these ordinations took place on occasions when neither the bishop of Worcester nor a suffragan appears to have held an ordination ceremony in the diocese. 45 However, members of the regular clergy appear occasionally to have been ordained by neighbouring bishops even though their own diocesan was himself active locally in that capacity. For example, two monks of Great Malvern, John Cookley and John Weston, were ordained deacon by bishop Trefnant of Hereford at Ledbury on 31 May 1393, the same day that Bishop Wakefield held an ordination ceremony in Worcester Cathedral. $4^{6}$ One factor that doubtless influenced the decision to be ordained in a particular alternative diocese was the distance to be travelled. 47 It is not surprising that many of the monks and canons from the diocese of Worcester who went to be ordained elsewhere were of religious houses located relatively close to the diocesan boundary. Thus, many of the 262 or so religious from the diocese of Worcester who were ordained at least once by a bishop of Lichfield were members of houses in the northern

45 Davis, 'Episcopal ordination lists as a source', 160.

$4^{6}$ A calendar of the register of Henry Wakefeld, bishop of Worcester, I375-95, ed. Warwick Paul Marett (Worcestershire Historical Society n.s. vii, 1972), 220-1; Registrum Johannis Trefnant, episcopi Herefordensis, A.D. MCCCLXXXIX-MCCCCIX, ed. W. W. Capes (Canterbury and York Society xx, 1916), 206-7.

47 Davis, 'Episcopal ordination lists as a source', $158-60$. 
and eastern regions of the diocese, close to the diocesan boundary with Lichfield. An important source of evidence for ordination elsewhere was the issuing of letters dimissory, and in some cases, there is a record of both ordination in another diocese and the relevant contemporaneous letters dimissory. For example, the register of bishop Wakefield records the issue on 13 September 1392 of letters dimissory for ordination to all orders for five canons of Llanthony by Gloucester who were duly ordained by Bishop Trefnant of Hereford just over a week later at Churcham, Gloucs. $4^{8}$ In many instances, however, a copy of the letter dimissory survives but no equivalent record of ordination occurs in the registers of the neighbouring dioceses, and in a few cases the letter dimissory is the only extant evidence that a particular monk or canon was ever ordained. For instance, William Brit, of St Peter's Gloucester, who received a letter dimissory to be ordained priest on 22 May 1374, occurs in various documents as a monk of Gloucester between 1379-96, but no other record of his being ordained to any order has been found. 49 Gaps in the registers of neighbouring dioceses may explain at least some of these cases, but it is also possible that monks and canons sometimes went further afield to be ordained. For example, the registers of the bishops of Winchester contain a handful of ordinations of religious from the diocese of Worcester. $5^{\circ}$

Two of the religious houses covered by this study were, for different reasons, technically not under the jurisdiction of the bishop of Worcester, and in these cases different arrangements for the ordination of their respective brethren might be made. For historical reasons, St Oswald's Priory, Gloucester, along with its dependent liberty of Churchdown, lay within the jurisdiction of the see of York..$^{1}$ However, the canons of St Oswald's appear not to have chosen to make the $15^{0}-$ mile journey north to be ordained by the archbishops of York. A glance through the ordination lists in the York archiepiscopal registers $5^{2}$ does not reveal any Gloucester canons, though a few letters dimissory to

$4^{8}$ Register of Henry Wakefeld, 21 7; Registrum Johannis Trefnant, 202-3. Churcham lay in the part of Gloucestershire that was in the medieval diocese of Hereford.

49 Registrum sede vacante, 302; TNA, E179/58/5; Calendar of papal registers, iv. 296; v. 30 .

$5^{\circ}$ Hampshire Record Office, Winchester, MSS Al / 13, fo. Xv (Bordesley); Al / 14, fo. $173 \mathrm{r}$ (Evesham); A1/16, fo. 29v (2x Worcester priory), $32(=34) \mathrm{v}$ (Bristol Austin friars). See also The episcopal registers of the diocese of St. David's ${ }_{3} 397$ to ${ }_{5}{ }_{1} 8$, ed. and trans. R. F. Isaacson, London 1917 , ii.704-6, 710.

$5^{1}$ Hamilton Thompson, 'The jurisdiction of the archbishops of York in Gloucestershire, with some notes on the history of the priory of St Oswald at Gloucester', Transactions of the Bristol and Gloucestershire Archaeological Society xliii (1921), 85-180; Jeffrey Howard Denton, English royal free chapels, I I oo- I3oo: a constitutional study, Manchester 1970, $5^{1-7}$.

$5^{2}$ University of York, York's archbishops registers revealed, <https://archbishopsregisters.york.ac.uk/home_page/index $>$. 
Gloucester canons can be found. For the period before about $145^{\circ}$, the vast majority of these ordination events are recorded in non-Worcester registers, especially those of Hereford, but after that date, the registers from Worcester do increasingly record the ordination of canons of St Oswald's. In addition, Evesham Abbey was one of a small number of medieval English Benedictine houses that were exempt from local episcopal intervention, which included the bishop's right to visitation, hospitality, excommunication and ordination.53 Thus, a mere six ordination events for monks of Evesham have been found in the registers of the bishops of Worcester, all dating from the fourteenth century. 54 With these few exceptions, all the ordinations of monks of Evesham recorded in episcopal registers occur in those of bishops of other dioceses, especially those of Hereford and, after about 1400, Coventry and Lichfield. Furthermore, the abbot of Evesham himself possessed quasi-episcopal 'peculiar' jurisdiction over a number of dependent parishes within the Vale of Evesham, and while the abbot's jurisdiction did not extend to such sacramental powers as ordination and consecration, he was free to call in any bishop from outside to hold ordinations and could also himself issue letters dimissory. Accordingly, the register of Abbot Richard Bromsgrove $(1418 \times 1434)$ contains the record for five small ordination ceremonies celebrated by suffragan bishops at Evesham Abbey during the period 1421-31, where the ordinands included not only monks of Evesham but also other religious, from Alcester, Hailes and Gloucester, as well as secular clergymen.55 If these five lists from Evesham were not unique but indicate that the abbots did indeed periodically organise local ordination ceremonies, then the poor rate of correspondence between the conventual lists for Evesham Abbey and the surviving episcopal ordination lists could in part be a result of this practice. Furthermore, among the ten religious ordained at Evesham on 16 March 1431 was John Coventry, monk of Hailes, for whom no other record of ordination is known. It is not impossible therefore that other non-Evesham regulars were also ordained during such ceremonies and thereby did not need to seek ordination at the more regular

53 David Knowles, 'Essays in monastic history, IV: The growth of exemption', Downside Review l (1932), 201-31, 396-436 at pp. 396-401; R. N. Swanson, 'Peculiar practices: the jurisdictional jigsaw of the pre-Reformation Church', Midland History xxvi (2001), 69-95 at pp. 73, 89, and Church and society, 16-24.

54 The register of Walter Reynolds, bishop of Worcester, I308-I3 I3, ed. Rowland Alwyn Wilson (Dugdale Society ix, 1928), 142; Calendar of the register of Adam de Orleton, bishop of Worcester, I327-1333, ed. R. M. Haines (Worcestershire Historical Society n.s. xxvii, 1979), 4; Register of Henry Wakefeld, 199.

55 BL, ms Cotton Titus C.IX, fos $17 \mathrm{r}$, 33v-34r; G. R. C. Davis, Medieval cartularies of Great Britain and Ireland, rev. Claire Breay, Julian Harrison and David M. Smith, London 2010,78 , no. $3^{8} 5$. 
and larger ceremonies held by their diocesan or by a bishop from a neighbouring diocese.

Some of the Worcester diocese monks and canons who appear in a conventual list for a particular religious house but are not in the extant ordination lists may be missing because they had been ordained under different circumstances: either as members of another religious house (or even another religious order) or as secular clergy. The appointment of a new superior from another house, usually through external interference, is of course relatively well attested. $5^{6}$ For this reason abbots and priors named in the conventual lists are counted separately from their brethren (see appendix 1). The evidence for the diocese of Worcester would confirm Martin Heale's conclusions that superiors appointed from another house were especially frequent among lesser Augustinian houses and some smaller Benedictine priories. 57 Cases where the house of origin of a new superior is not known are also most common among the same houses and also the exempt Cistercian and Premonstratensian monasteries. In addition, however, cloister monks and canons could sometimes be transferred to another religious house at some point after ordination. This transfer (transitus or migratio) might be to a house of the same order or even, in a few cases, of an entirely different order..$^{8}$ In such cases, if the transferee had been ordained priest before moving to another house, then he would not appear earlier among the ordinands of his new house. Donald Logan has stated that ' $[\mathrm{t}]$ he presence, then, of a transferred religious in a religious house was probably a fairly common occurrence'.59 Indeed, a Worcester Cathedral Priory register records the transfer arrangements for nine monks of Worcester between 1507 and 1530 , that is, an average of one every two and a half years. ${ }^{60}$ Among these Worcester monks was William Overbury, whose licence to transfer to Winchcombe Abbey is dated 6 November $15^{27}$, and who had been ordained priest in the previous June. ${ }^{61}$ He appears in a number of conventual lists for Winchcombe ( 1534

$5^{6}$ For the election and selection of superiors see Heale, The abbots and priors, $15^{-} 5^{6}$.

57 Idem, "Not a thing for a stranger to enter upon": the selection of monastic superiors in late medieval and early Tudor England', in Janet Burton and Karen Stöber (eds), Monasteries and society in the British Isles in the later Middle Ages, Woodbridge 2008, 51-68. See also Heale, The abbots and priors, 28, 34-5, 43-4.

${ }^{8}$ Logan, Runaway religious, 43, 45; Greatrex, English Benedictine cathedral priories, 85 ; James Clark, 'Why men became monks in late medieval England', in P. H. Cullum and Katherine J. Lewis (eds), Religious men and masculine identity in the Middle Ages, Woodbridge 2013, 16o-83 at p. 180; Supplications, i. 5, 15 .

59 Logan, Runaway religious, 45 .

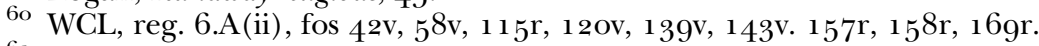

${ }^{61}$ Joan Greatrex, Biographical register of the English cathedral priories of the province of Canterbury, c. Io66 to I540, Oxford 1997, 860; WRO, b706.093-BA2648/9(i), p. 164. 
and $\left.{ }_{1539}\right)^{62}$ but of course does not occur in any earlier ordination lists as a member of that abbey. Without such documentation, cases of transfer between houses are not readily apparent. A number of monks and canons bore monastic toponymic surnames that were also the locations of other religious houses of the same order, and it is possible that some of these at least may reflect movement between houses. Numerous examples can be found among the Cistercians in particular: 63 these include a handful of sixteenth-century monks of Hailes who bore toponymic surnames derived from the houses at Whalley and Sallay/Sawley (both Lancs.) and Kirkstall (Yorks.) and who, David Bell has suggested, may have started their monastic lives at those northern monasteries. ${ }^{6} 4$ Transfer to another house was normally expected to be permanent, though this was not always the case. ${ }^{65}$ In addition, some regulars were sent on temporary 'exile' to another house for purposes of punishment and penance, which might last for a short period of time but could be up to five or seven years, or longer. ${ }^{66}$ It would be interesting to determine whether such exiled brothers would appear in the conventual lists of their 'home' monastery or that of their exile.

Members of the secular clergy might occasionally seek to become regulars, sometimes when still relatively young but sometimes in old age. ${ }^{67}$ P. H. Cullum, for example, has suggested two such cases from the diocese of Worcester in the register of Bishop Henry Wakefield. ${ }^{68}$ In these instances the men in question had not completed the process of ordination before being admitted, but those secular clerks who had already been ordained priest, before professing as a religious, would be more difficult to detect in the sources. For example, John Green, prior of Worcester Cathedral Priory between 1388 and 1395, is mentioned in conventual lists for 1373 and 1379 but cannot be found in the surviving ordination lists as a monk of the priory. ${ }^{69}$ In fact, he has been identified as the secular clerk John Grene, scholar of Merton Hall, Oxford, ordained

${ }^{62}$ LPL, London, ms Cartae Antique et Misc. xi.56; TNA, E25/1 20/1; E $315 / 494 / 1$, pp. $75^{-6 .}$.

${ }_{63}$ See also David H. Williams, The Welsh Cistercians, Leominster 2001, 129.

64 David N. Bell, 'The cartulary of Hailes Abbey: 1469-1539', Citeaux: Commentarii Cistercienses $\mathrm{lx}$ (2009), 79-138 at p. 86.

${ }_{5}$ For example, Richard Cleeve, monk of Worcester, transferred to the Cluniac priory at Dudley in April 1524 , but seems to have returned to Worcester within a decade, if not sooner: WCL, reg. A.6(ii), fo. 143v; TNA, E25/122/3; DKR vii, appendix ii, p. 305; Greatrex, Biographical register, 788 .

66 Logan, Runaway religious, 149-5 1; Knowles, Religious orders in England, i. 93; ii. 214.

67 Thomson, Early Tudor Church and society, 189 ; Clark, 'Why men became monks', 180-1; Greatrex, English Benedictine cathedral priories, $5^{1 .}$

68 Cullum, 'Man/boy', 60.

69 Registrum sede vacante, 290; TNA, E1 79/58/11. 
subdeacon and deacon in $1368-9.7^{\circ}$ In Green's case, it may be wondered whether the retention of his presumably hereditary surname (Green as topographical feature, not colour) rather than the assumption of a monastic 'toponym of origin' may be indicative of his post-ordination admission as monk. At least some of the other religious with non-toponymic surnames may similarly have been former secular clergymen who became regulars either during or after the years of ordination. Thus, among the regulars named in the clerical subsidy lists for 1379 for whom, like Green, no ordination records survive are William Ffaukoner, monk of Gloucester; John Samon and John Lange, both canons of Bristol; and, William Conys, monk of Winchcombe. ${ }^{71}$

While monks were expected to spend most of their lives in the cloister of their monastery, a number of factors might take them out of the house, perhaps for extended periods, such as the appointment of one of the brethren to serve as vicar for an appropriated church. In the latter case, because only a man who had been ordained priest was allowed to say mass, it is hardly like that non-priests would be sent. This is supported by a cursory glance through the ordination lists. The conventual lists drawn up as part of Bishop Redman's visitations of the Premonstratensians in the late fifteenth century name canons of Halesowen who were vicars variously of Clent, Hales and Walsall in 1475 and between 1491 and 1497 , and in all cases the individuals in question can be found in the ordination lists, mostly decades earlier. $7^{2}$ Potentially more promising are those monasteries, especially Benedictine houses, that had dependent priories, normally populated by a handful of monks from the mother house. The weight of evidence however would support the view that regulars who occupied such dependent priories had been ordained earlier, while associated with their mother house. Indeed, Martin Heale has pointed out that monks of such cells 'rarely' appear in the ordination lists.73 Thus, conventual lists from St Peter's Abbey, Gloucester, relating to abbatial elections in $15^{10}$ and 1514 , name the monks resident at the dependent priories of Bromfield, Ewenny, St Guthlac's (Hereford) and Stanley St Leonard's, 74 and all had been ordained priest as monks of Gloucester before being sent to the cells, often a few decades earlier. The only exception to this are a handful of earlier instances in the registers of the bishops of Hereford of the ordination of regulars termed 'monks of S. Guthlac's',

$7^{\circ}$ Greatrex, 'Prosopography', 9, and Biographical register, 81 2-13; Registrum Thome de Charlton, 116,119 .

$7^{1}$ TNA, E179/58/5; E1 79/58/54.

$7^{2}$ Richard Hill (ord. 1438-42; vic. Hales 1475, 1491-4); John Combar (ord. 1440-2 +; vic. Walsall 1475); John Hay (ord. 1453-8; vic. Clent 1475, 1491-7); John Saunders (ord. 1463-7; vic. Hales, 1497); and John Seede (ord. 1476-9; vic. Clent 1488, vic. Walsall $149^{1-7)}$.

73 Heale, Dependent priories, 117.

74 GCL, reg. C (Newton), fos 2r-33r; reg. Malvern I (D), fos 2v-[46]. 
all of whom are also attested in previous ordination lists as monks of Gloucester: John Stratford (subdeacon, 1375), John Newton (priest, 1482) and Thomas Hampton (priest, 1484).75 Only in cases when a dependent priory had become effectively independent from its mother house is there local recruitment and the regular ordination of its inmates. For the diocese of Worcester, although Great Malvern Priory was technically a cell of Westminster Abbey, there is no evidence for any involvement of the priory's nominal mother house in the ordination of its brethren during the later Middle Ages..$^{6}$

The conclusion is similar for those monks and canons who attended university. 77 It is usually estimated that monks entered university in their early to mid-twenties, and this would certainly overlap with the process of ordination for most, $7^{8}$ the minimum age for the priesthood being twenty-four. Indeed, David Knowles emphasised that those religious whose houses were especially far from Oxford or Cambridge "were therefore all but strangers to their monastery from their mid-twenties to their mid-thirties'.79 For the more than $15^{\circ}$ monks and canons of houses in the diocese of Worcester known to have been students at Oxford, ${ }^{80}$ records of ordination survive for the vast majority, and most appear to have completed their progress through holy orders before being sent to university by their superiors. For instance, the supplication of the Evesham monk Hugh Bromsgrove indicates that by May $15^{13}$ he had spent at least seven years studying, both at university and in his cloister, which would place his arrival at Oxford in ${ }^{1} 5^{\mathrm{o} 6}$ - the same year that he was ordained priest. ${ }^{81}$ However, some Worcester diocese regulars do appear to have undergone ordination while at university. John Rodley, monk of St Peter's Gloucester, may have

75 Registrum Willelmi de Courtenay, episcopi Herefordensis, A.D. MCCCLXX-MCCCLXXV, ed. William W. Capes (Canterbury and York Society xv, 1914), 54; Registrum Thome Myllyng, episcopi Herefordensis, A.D. MCCCCLXXIV-MCCCCXCII, ed. Arthur Thomas Bannister (Canterbury and York Society xxvi, 1920), 165, 170-1; WRO, b7o6.093BA2648/4(iii), p. 55; b7o6.o93-BA2648/7(i), pp. 261, 273.

$7^{6}$ E. H. Pearce, The monks of Westminster, Cambridge 1916.

77 R. B. Dobson, 'The religious orders, 1370-1540', in J. I. Catto and Ralph Evans (eds), The history of the University of Oxford, II: Late medieval Oxford, Oxford 1992, 539-79.

$7^{8}$ Ibid. 567; Greatrex, English Benedictine cathedral priories, $5^{1 .}$

79 Knowles, Religious orders in England, ii. 22.

80 The majority were collected in BRUO, and A. B. Emden, A biographical register of the University of Oxford, A.D.I5OI-154O, Oxford 1974. See also P. Cunich, 'Benedictine monks at the University of Oxford and the dissolution of the monasteries', in Henry Wansbrough and Anthony Marett-Crosby (eds), Benedictines in Oxford, London 1997, $155^{-82 .}$

81 Register of congregations, I5O5-I5I 7 , ed. W. T. Mitchell (Oxford Historical Society n.s. xxxvii-xxxviii, 1998), ii. 274-5; Chippenham, Wiltshire and Swindon Archives, Chippenham, Bishops' registers D/2 (reg. Audley); Emden, Biographical register A.D. $1501-1540,75$. 
gone up to Oxford around ${ }^{1504-5}$, and became bachelor of divinity in $15^{14}$, but was not ordained acolyte until $1506{ }^{82}$ No other ordination records survive for him, though it is known that he had been ordained priest by $15^{10}$, when still at Oxford. It is an interesting fact that we have evidence of the ordination in 1497-8, at Oxford itself, of two monks of Worcester - William Alston and William Barndesley - by the bishop of Lincoln, at St Frideswide's Priory and at Osney Abbey. ${ }^{83}$ For a few monkstudents there are no surviving ordination records at all, and it might be postulated whether other arrangements were made for these men while they were studying: examples include Thomas Atherbury, canon of Cirencester, described as scholar at Oxford at the time of Archbishop Morton's visitation in $1498 .{ }^{84}$ For the most part, however, it does not seem likely that spending time at university - whether continuously over many years or for a shorter period with frequent visits to the mother house-caused many monks and regular canons of the diocese of Worcester to be omitted from the ordination lists.

Assessing the ordination lists by using conventual lists from the period ${ }^{1} 53^{6}-4^{\mathrm{O}}$ is fraught with difficulties and uncertainties. The surviving ordination lists from the diocese of Worcester peter out by $153^{2-3}$, though there is independent evidence that religious clergy were still being ordained after this time. Furthermore, the conventual lists from the Dissolution years, mostly pension lists plus a few deeds of surrender, are themselves problematic. For instance, of the sixty conventual lists (surrenders and/or pensions) dating from the period ${ }^{1538-40}$, as many as twenty-five (about 40 per cent) refer to the monks and canons by only employing their nonmonastic, hereditary surnames (see appendix 1), and this of course renders it difficult to identify these individuals in the earlier ordination lists, where they invariably use their monastic names. However, because many conventual lists named the monks or canons according to seniority, it might be possible to compare the surrender and pension lists with the slightly earlier lists from ${ }_{1534}$ in order to identify the men named in the former. By way of illustration, the first column of table 3 gives the names of the abbot plus twenty canons of Cirencester who took the Oath of Supremacy in 1534 and reproduces the order of signatures exactly as appears on the extant manuscript. ${ }^{85}$ Fifteen out of these twenty-one brethren of Cirencester can be found in the ordination lists, with the same

${ }^{82}$ BRUO, 489-90; Register of congregations $1505-15$ I 7, ii. 147, 324; Registrum Ricardi Mayew, episcopi Herefordensis. A.D. MDIV-MDXVI, ed. Arthur Thomas Bannister (Canterbury and York Society, 1921), 246; GCL, reg. Newton (C), fos 2r-36r; reg. Malvern I (D), fos 2v-46.

${ }^{83}$ BRUO, i. 28, 11 2; Greatrex, Biographical register, 769, 774; Lincolnshire Archives, Lincoln, episcopal register XXIV (Smith), fos 6v, 12 r. Alston was ordained subdeacon on 23 December 1497 by the bishop of Winchester: Greatrex, Biographical register, 769 .

${ }_{4}$ Register of John Morton, ii. 131.

85 TNA, E25/31. 
Table 3. Canons of Cirencester, 1534, $154^{\circ}$

\begin{tabular}{ll}
\hline \hline 1534 & 1540 \\
\hline John, abbot & John Blake, abbot \\
Richard Cirencester & Richard Woodall \\
William Cerney & William Warbott \\
William Hagbourne & William Phillips \\
John Dorney & \\
John Aston & \\
Thomas Bray & Thomas Fisher \\
Thomas Brinkworth & Thomas Hodde \\
John Pullan & John Russell \\
John Wall & John Walle(y) \\
Richard Hereford & William More \\
William Burton & Richard Bolle \\
John Evesham & John Strange \\
William Gloucester & \\
Richard Sodbury & \\
Thomas Woodstock & Thomas Logger \\
Anthony Salisbury & Anthony Chilcock \\
James Exeter & Henry Hawks \\
Henry Worcester & James Perlebien \\
Richard Cheltenham-William Smith \\
William Castleton
\end{tabular}

monastic surnames as given in 1534 . The second column gives the names from a number of pension lists for Cirencester Abbey dated 1540, again giving the order of names as in the originals, but here the surnames (with one possible exception) are different. ${ }^{86}$

Comparing the two sets of lists, it can be noted that the order of forenames is compellingly similar, although the 1540 lists are shorter and, in a few cases, the order of some consecutive pairs of names has been reversed. There are grounds, therefore, for identifying the individuals named in the two sets of lists with one another. Similar comparisons could be made for other houses for which there are complete conventual list from the early 153 os. In those cases where no such evidence has survived - for example, from 1534 for the Cistercian houses of Bordesley, Hailes and Kingswood - any attempt to identify monks named in the ordination lists with individuals in the pension lists is problematic to say the least.

Finally, some monks and canons who are named in conventual lists from the period of the Dissolution but are missing from the earlier ordination

86 TNA, E $315 / 245$, fo. 45 ; $L P$ xiv/2, $260 ; M A$ vi/1, 178 ; TNA, E $315 / 494 / 1$, fo. 59 ; G. Baskerville, 'The dispossessed religious after the suppression of the monasteries', Transactions of the Bristol and Gloucestershire Archaeological Society xlix (1927), 63-122 at pp. 93-4. 
lists may be absent because, like those monastic transferees and exiles, they had not been members of the relevant house when being ordained. It is well known that during the suppression of smaller religious houses (those valued in 1536 at less than £200), their inmates were either offered the chance to take a dispensation from their monastic vows and become secular priests or alternatively, if they wished to remain in the religious state, to be moved to a larger house of the same order. ${ }^{8} 7$ David Knowles estimated that, from those smaller houses that were surrendered in $153^{6-7}$, about half the religious opted to become seculars. ${ }^{88}$ This means of course that about half chose to remain in religion and needed to be accommodated elsewhere; and they ought therefore to occur in the conventual lists of $1538-40$ when their new houses were in turn 'voluntarily' surrendered. The evidence for the diocese of Worcester specifically is inconclusive in this respect however. For the four male religious houses dissolved in 1536-7 (St Oswald's Gloucester, Little Malvern, Studley and St Sepulchre's Warwick), it has not been possible to trace any of their brethren among the later surrender deeds or pension lists of other houses in the diocese. In the cases of St Oswald's and Studley, it seems likely that the whole community of each priory chose to leave religion in $153^{6-7}$, even though in the case of the former house most brethren had previously stated their intention of remaining in religion. ${ }^{89}$ This would support Geoffrey Baskerville's assertion that Augustinian canons were 'the most indifferent' to remaining in religion. $9^{\circ}$ In contrast, he also stated that the Cistercians in particular were the most fervent in continuing as religious clergy, sometimes with all the monks remaining. ${ }^{11}$ It is difficult to determine whether any of the ex-monks of Bordesley, Hailes or Kingswood abbeys had previously been members of other Cistercian houses because (again), for these three monasteries, non-monastic surnames are invariably given in the relevant surrender and pension lists.

A comparison of the ordination lists preserved in the extant registers of Worcester and neighbouring dioceses with 178 conventual lists for religious houses in the diocese of Worcester during the period from about 1300 to 1540 indicates that, on average, a little under 75 per cent of monks and canons named in the conventual lists occur at least once in the ordination lists. This means that over 25 per cent of religious in the

\footnotetext{
87 Knowles, Religious orders in England, iii. 304-1 1; Geoffrey Baskerville, English monks and the suppression of the monasteries, New Haven 1936, 144-55. Only superiors were pensioned off at this stage.

88 Knowles, Religious orders in England, iii. 311.

${ }^{89}$ FOR, 88, 89; Sybil M. Jack, 'Dissolution dates for the monasteries dissolved under the act of 1536', Bulletin of the Institute of Historical Research xliii (1970), 161-81 at pp. 171, 178; F. A. Gasquet, 'Overlooked testimonies to the character of the English monasteries on the eve of their suppression', Dublin Review cxiv (1894), 245-77 at p. 276 .

$9^{\circ}$ Baskerville, English monks, 148. $9^{1}$ Ibid. 149 .
} 
conventual lists are not mentioned in the surviving episcopal ordination lists. The irregular survival of ordination lists accounts for a significant proportion of these figures, especially for the first half of the fourteenth century and for the 153 os. For the period $135^{\circ-1} 530$, the not-infrequent occurrence of sometimes quite lengthy gaps in the ordination record in the registers of the bishops of Worcester (some as much as 3-4 years) may in turn account for more than half of the other omissions. While it should be emphasised that the evidence cited here relates to one diocese only, the ordination lists in many other dioceses' registers do contain similar gaps, to varying degrees..$^{2}$ Other factors - independent of the ordination lists themselves - may explain at least some of the remaining omissions. Clearly, for a prosopographical study of most religious houses in late medieval England, ordination lists alone are insufficient alternatives to the admission, profession and obituary lists that survive for only a handful of cathedral priories. For as thorough an analysis of the personnel of the majority of monasteries as possible, the testimony of the ordination lists should be supplemented by drawing upon any surviving conventual lists (themselves neither always complete nor very numerous) as well as by collecting individual references to religious clergy in miscellaneous ecclesiastical and non-ecclesiastical sources.

$9^{2}$ At one extreme, ordinations from the diocese of Norwich only survive for $14^{1} 3^{-}$ 86, 15 o2, and from 1532 to the dissolution: J. F. Williams, 'Ordinations in the Norwich diocese in the fifteenth century', Norfolk Archaeology xxxi (1956), 347-58; Smith, Guide, $15 \mathrm{o}, 162$. Even the relatively full lists for the archdiocese of York have some gaps in the fourteenth and early fifteenth centuries. 


\section{APPENDIX 1}

Conventual Lists, by Religious House

\begin{tabular}{|c|c|c|c|c|c|c|}
\hline House & Date & Type of list & Source & Monks total & Monks ordained & $\%$ \\
\hline \multirow[t]{2}{*}{ Alcester Abbey } & 1379 & Taxation & TNA, E179/58/11 & $5+$ abbot & $4 ?$ & 66 \\
\hline & 1498 & Visitation & Reg. Morton, ii. $13^{2}$ & $2+$ prior & $\mathrm{O}$ & o \\
\hline \multirow{9}{*}{$\begin{array}{l}\text { Bordesley } \\
\text { Abbey }\end{array}$} & 1366 & Dispute & TNA, $\mathrm{E}_{31} 5^{/ 35}$, no. $5^{1}$ & $11+$ abbot & $9+$ abbot & $8_{3}$ \\
\hline & 1379 & Taxation & TNA, E179/58/11 & $13+$ abbot & $11+$ abbot & 86 \\
\hline & 1538 & Dispensations & $F O R, 149$ & $19+$ abbot & non-monastic surnames & \\
\hline & 1538 & Pensions & TNA, E314/77 & $18+$ abbot & non-monastic surnames & \\
\hline & 1538 & Pensions & TNA, $\mathrm{E}_{315} / 233 ; L P \times \mathrm{xiv} / 1,597$ & $18+$ abbot & non-monastic surnames & \\
\hline & 1538 & Surrender & TNA, E $322 / 26 ; D K R$ viii, appendix ii, p. 11 & $19+\mathrm{abbot}$ & non-monastic surnames & \\
\hline & $1538 ?$ & Pensions & TNA, $\mathrm{E}_{314} / 2 \mathrm{O} / 11$, fo. $5^{\mathrm{V}}$ & $18+$ abbot & non-monastic surnames & \\
\hline & 1541 & Tax on pensions & Bodl. Lib., Ms Tanner 343, pp. 1-2 & $18+$ abbot & non-monastic surnames & \\
\hline & $1555^{-6}$ & Pensions & BL, MS Add. 8102; TNA, E164/31 & 11 & non-monastic surnames & \\
\hline \multirow{11}{*}{$\begin{array}{l}\text { Bristol, St } \\
\text { Augustine's }\end{array}$} & $1352 / 3$ & Election & Reg. sede vacante, 193-8 & $16+2$ abbots & 2 & 11 \\
\hline & 1379 & Taxation & TNA, E1 $19 / 58 / 5$ & $19+\mathrm{abbot}$ & 13 & 65 \\
\hline & $1491-2$ & Computus roll & Two computus rolls, 134,164 & $17+$ abbot & $17+$ abbot & 100 \\
\hline & 1498 & Visitation & Reg. Morton, ii. 130 & $20+a b b o t$ & $19+$ abbot & 95 \\
\hline & $1503-4$ & Account & Sabin , 'Computus rolls', 200-1 & $19+$ abbot & $17+$ abbot & 90 \\
\hline & $15^{07}$ & Account & Sabin , 'Computus rolls', 200-1 & $20+a b b o t$ & $18+$ abbot & 90.5 \\
\hline & $1511-12$ & Account & Two computus rolls, 135,165 & $17+$ abbot & $16+$ abbot & 94 \\
\hline & 1534 & Supremacy & TNA, E25/17; DKR vii, appendix ii, p. 281 & $18+$ abbot & $9+$ abbot & 53 \\
\hline & 1539 & Pensions & 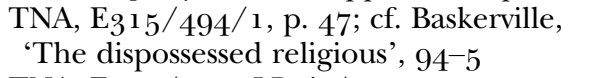 & $11+$ abbot & & \\
\hline & 1539 ? & Pensions & TNA, $\mathrm{E}_{31}{ }^{1} / 245 ; L P$ xiv $/ 2,241$ & $11+$ abbot & $4+$ abbot & 42 \\
\hline & 1540 & Pensions & TNA, $3^{1} 5^{/ 234}$, fos $183^{v-186 v ; ~ L P ~ x v . ~} 549$ & $11+$ abbot & & \\
\hline
\end{tabular}


APPENDIX (Cont.)

\begin{tabular}{|c|c|c|c|c|c|c|}
\hline House & Date & Type of list & Source & Monks total & Monks ordained & $\%$ \\
\hline & $155^{2-3}$ & Pensions & $\begin{array}{l}\text { TNA, E1o1/76/14; Baskerville, 'The dispos- } \\
\text { sessed religious', 99, } 112\end{array}$ & 5 & & \\
\hline & $1555^{-6}$ & Pensions & BL, MS Add. $8102 ;$ TNA, E164/31 & 5 & 1 & 20 \\
\hline \multirow{7}{*}{$\begin{array}{l}\text { Bristol, St } \\
\text { Marks } \\
\text { Hospital }\end{array}$} & 1346 & Election & Reg. Bransford, 131, 133 & $10+$ master & 1 & 9 \\
\hline & 1379 & Taxation & TNA, E1 $79 / 58 / 5$ & $6+$ master & 2 & 29 \\
\hline & 1498 & Visitation & Reg. Morton, ii. 130 & $4+$ master & $4+$ master & 100 \\
\hline & 1534 & Supremacy & TNA, E25/18; DKR vii, appendix ii, p. 281 & $4+$ master & $2+$ master & 60 \\
\hline & 1539 & Pensions & $L P$ xiv $/ 2,241$ & $3+$ master & & \\
\hline & 1539 & Pensions & TNA, E ${ }_{315} / 494 / 1$, fo. 53 & $3+$ master & $1+$ master & $5^{0}$ \\
\hline & $154^{\circ}$ & Pensions & TNA, E $315 / 234$, fos $191 \mathrm{r}-192 \mathrm{r} ; L P$ xv. 549 & $3+$ master & & \\
\hline \multirow{10}{*}{$\begin{array}{l}\text { Cirencester } \\
\text { Abbey }\end{array}$} & 1307 & Election & Reg. sede vacante, 99-101 & $23+$ abbot & $4 ?$ & 17 \\
\hline & $135^{2}$ & Election & WRO, b67o6.o93-BA2648/3(iii) 9o-1 & $27+$ abbot & 21 & 75 \\
\hline & $149^{8}$ & Visitation & Reg. Morton, ii. 131 & $22+$ abbot +2 & $18+$ abbot & 83 \\
\hline & $15^{11}$ & Visitation & Reg. Llanthony, 98 & $23+$ abbot & $19 / 20+$ abbot & $07 \cdot 5$ \\
\hline & 1534 & Supremacy & $D K R$ vii, appendix ii, no. $3^{1}$ & $20+$ abbot & $14+$ abbot & 71 \\
\hline & 1539 & Pensions & $\begin{array}{l}\text { TNA, } \mathrm{E}_{315} \text { / 494/1, fo. 59; Baskerville, 'The } \\
\text { dispossessed religious', } 93-4\end{array}$ & $16+$ abbot & non-monastic surnames & \\
\hline & 1540 & Pensions & TNA, E $315 / 234$, fos $23 \mathrm{Ov}-234 \mathrm{r} ; L P \mathrm{xv} .55^{\mathrm{O}}$ & $16+$ abbot & non-monastic surnames & \\
\hline & $154^{\circ}$ & Pensions & $\begin{array}{l}\text { TNA, E } 315 / 245 \text {,fo. } 45 ; L P \text { xiv } / 2,260 ; M A \text { vi } / 1 \text {, } \\
178\end{array}$ & $16+$ abbot & non-monastic surnames & \\
\hline & $155^{2-3}$ & Pensions & $\begin{array}{l}\text { TNA, E101/76/14; Baskerville, 'The dispos- } \\
\text { sessed religious', 100, } 110,112\end{array}$ & $9+$ abbot & non-monastic surnames & \\
\hline & ${ }^{1} 555^{-6}$ & Pensions & $\begin{array}{l}\text { BL, ms Add. 8102; TNA, E164/31; cf Taylor, } \\
\text { 'Religious houses', } 114\end{array}$ & $8+1$ & non-monastic surnames & \\
\hline \multirow{3}{*}{$\begin{array}{l}\text { Evesham } \\
\text { Abbey }\end{array}$} & 1345 & Election & TNA, E135/2/26 & $37+$ abbot & $7+$ abbot & 21 \\
\hline & 1379 & Taxation & TNA, E179/58/11 & & & \\
\hline & 1418 & Election & BL, ms Cotton Titus C.ix fos $1 \mathrm{r}-2 \mathrm{v}$ & $3^{1}$ & $19 / 20$ & $64 \cdot 5$ \\
\hline
\end{tabular}




\begin{tabular}{|c|c|c|c|c|c|c|}
\hline \multirow{7}{*}{$\begin{array}{l}\text { Gloucester, St } \\
\text { Oswald's }\end{array}$} & \multirow{5}{*}{$\begin{array}{l}1539 / 4^{\circ} \\
154^{\circ} \\
154^{\circ} \\
154^{\circ} \\
1555^{-6}\end{array}$} & \multirow{5}{*}{$\begin{array}{l}\text { Pensions } \\
\text { Pensions } \\
\text { Surrender } \\
\text { Pensions } \\
\text { Pensions }\end{array}$} & \multirow{5}{*}{$\begin{array}{l}\text { TNA, } \mathrm{E}_{315} / 245 \text {, fo. } 105 \\
L P \text { xv. } 37^{-8} \\
\text { Matthew Bible* } \\
\text { TNA, } 315 / 234 \text {, fos } 203 \mathrm{v}-211 \mathrm{v} ; L P \text { xv. } 55^{\mathrm{O}} \\
\text { BL, MS Add. } 8102 \text {; TNA, E164/31 }\end{array}$} & \multicolumn{3}{|l|}{$33+$ abbot } \\
\hline & & & & \multicolumn{3}{|l|}{$33+$ abbot } \\
\hline & & & & \multicolumn{3}{|l|}{$34+2$ abbots } \\
\hline & & & & $33+$ abbot & 9 & 25 \\
\hline & & & & 24 & 3 & 12.5 \\
\hline & \multirow{2}{*}{$\begin{array}{l}1537 \\
1538 ?\end{array}$} & \multirow{2}{*}{$\begin{array}{l}\text { Dispensation } \\
\text { Pensions }\end{array}$} & \multirow{2}{*}{$\begin{array}{l}F O R, 88 \\
\text { TNA, } \mathrm{E}_{315} / 23^{2}, \text { fo. } 3^{1 \mathrm{~V}}\end{array}$} & \multirow{2}{*}{$\begin{array}{l}6 \\
\text { prior only }\end{array}$} & \multirow[t]{2}{*}{6} & \multirow[t]{2}{*}{100} \\
\hline & & & & & & \\
\hline Gloucester, St & $133^{8-9}$ & Visitation & Reg. sede vacante, 281 & $4^{6+\text { abbot }}$ & $3^{\circ}$ & 64 \\
\hline \multirow[t]{13}{*}{ Peter's } & 1348 & Vicarage ord. & Reg. Bransford, 168 & $33+$ abbot & $24+$ abbot & $73 \cdot 5$ \\
\hline & 1379 & Taxation & TNA, E179/58/5 & $3^{6+\text { abbot }}$ & $29+$ abbot & 81 \\
\hline & 1498 & Visitation & Reg. Morton, ii. 119 & $53+$ abbot & $4^{6+\text { abbot }}$ & 87 \\
\hline & $15^{10}$ & Election & $\begin{array}{l}\text { GCL, Reg. Newton }(=\mathrm{C}) \text {; Hart, Historia, iii, } \\
\text { xxxii-xxxiv }\end{array}$ & $6_{5}+$ abbot & $62+$ abbot & $95 \cdot 5$ \\
\hline & $15^{14}$ & Election & $\begin{array}{l}\text { GCL Reg. Malvern I (=D); Hart, Historia, iii, } \\
\text { xlviii-xlix }\end{array}$ & $5^{6+\text { abbot }}$ & $53+$ abbot & 95 \\
\hline & 1534 & Supremacy & TNA, E25/58/1; DKR vii, appendix ii, p. 287 & $35+$ abbot & $27 / 28+$ abbot & 78 \\
\hline & $153^{8}$ & Dispensation & $F O R, 15^{8}$ & 12 & & \\
\hline & 1539 & Pensions & $\begin{array}{l}\text { TNA, } \mathrm{E}_{31}{ }_{5} / 494 / 1 \text {, fos } 94^{-} 5 \text {; Baskerville, 'The } \\
\text { dispossessed religious', } 81-4\end{array}$ & 27 & 17 & 65 \\
\hline & 1540 & Pensions & TNA, E $315 / 234$, fos 137 r-14or; $L P \times v .548$ & 14 & 9 & \\
\hline & 1540 & Pensions & TNA, E $315 / 245$, fo. 97; Hart, Historia, iii, liv & 14 & & \\
\hline & $c .1540$ & Ex-religious & WRO, Bell's Book, 188 & $18 ?$ & 14 & 78 \\
\hline & $155^{2-3}$ & Pensions & $\begin{array}{l}\text { TNA, E101/76/14; Baskerville, 'The dispos- } \\
\text { sessed religious', 102, 114, 120, } 122\end{array}$ & 16 & & \\
\hline & $1555^{-6}$ & Pensions & BL, MS Add. 8102; TNA, E164/31 & 15 & 11 & 73 \\
\hline \multirow{3}{*}{$\begin{array}{l}\text { Great Malvern } \\
\text { Priory }\end{array}$} & 1349 & Election & WAM, 32656 & $10+$ prior & $5+$ prior & $54 \cdot 5$ \\
\hline & 1361 & Election & WAM, 32657 & $10+$ prior & 7 & 63.5 \\
\hline & 1379 & Taxation & TNA, E179/58/11 & $14+$ prior & 12 & 80 \\
\hline
\end{tabular}


APPENDIX (Cont.)

\begin{tabular}{|c|c|c|c|c|c|c|}
\hline House & Date & Type of list & Source & Monks total & Monks ordained & $\%$ \\
\hline & 1382 & List of names & WAM, 22959B & $13+$ prior & $8 / 9$ & 64 \\
\hline & 1397 & Election & WAM, 22943 & $15+$ prior & $14+$ prior & 94 \\
\hline & 1540 & Pensions & $L P \times v .20 ; M A$ iii. $45^{1}$ & $11+$ prior & $9+$ prior & 80 \\
\hline & 1540 & Pensions & TNA, $315 / 234$, fos $145^{\mathrm{r}-147 \mathrm{v} ; L P \times v} .54^{8}$ & $11+$ prior & & \\
\hline & 1541 & Tax on pensions & Bodl. Lib., Ms Tanner 343, p. 1 & $12+$ prior & 9 & 69 \\
\hline & $1555^{-6}$ & Pensions & BL, MS Add. 8102; TNA, E164/31 & 7 & 7 & 100 \\
\hline \multirow[t]{9}{*}{ Hailes Abbey } & 1379 & Taxation & TNA, E1 $79 / 58 / 54$ & 16 & $9 / 10$ & 62.5 \\
\hline & 1420 & Election & BL, ms Royal 12.E.xiv, fos $7 \mathrm{OV}-71 \mathrm{r}$ & $8+$ abbot & incomplete list & \\
\hline & $1537-8$ & Attestations & $\begin{array}{l}\text { Shakespeare Birthplace Trust, Stratford, MS } \\
\operatorname{DR}_{18.31 .5} \text {, fo. } 54^{\mathrm{r}}\end{array}$ & 11 & 7 & 64 \\
\hline & 1539 & Pensions & TNA, $\mathrm{E}_{315} / 494 / 1$, fo. 67 & $21+$ abbot & non-monastic surnames & \\
\hline & 1539 & Pensions & TNA, $\mathrm{E}_{315} / 245 ; L P$ xiv $/ 2$, p. $291 ; \mathrm{MA}$, v. 689 & $21+$ abbot & non-monastic surnames & \\
\hline & 1540 & Dispensation & $F O R, 208$ & $21+$ abbot & non-monastic surnames & \\
\hline & 1540 & Surrender & TNA, E $3^{1} 5^{/ 234}$, fos $234^{\mathrm{V}-239 r ; L P x v} \cdot 55^{1}$ & $21+$ abbot & non-monastic surnames & \\
\hline & $155^{2-3}$ & Pensions & $\begin{array}{l}\text { TNA, E101/76/14; Baskerville, 'The dispos- } \\
\text { sessed religious', } 100,113,119\end{array}$ & 15 & non-monastic surnames & \\
\hline & $1555^{-6}$ & Pensions & $\begin{array}{l}\text { BL, MS Add. 8102; TNA, E164/31; cf. Taylor, } \\
\text { 'Religious houses', } 120\end{array}$ & 12 & non-monastic surnames & \\
\hline \multirow{10}{*}{$\begin{array}{l}\text { Halesowen } \\
\text { Abbey }\end{array}$} & 1379 & Taxation & TNA, E1 $79 / 5^{8 / 11}$ & $10+$ abbot & forenames only & \\
\hline & 1475 & Visitation & $C A P$ ii. $24^{\circ}$ & $18+$ abbot & $18+$ abbot & 100 \\
\hline & 1478 & Visitation & CAP ii. 243 & $18+$ abbot & $17+$ abbot & 95 \\
\hline & 1482 & Visitation & $C A P$ ii. 247 & $18+$ abbot & $16+$ abbot & 89.5 \\
\hline & 1488 & Visitation & $C A P$ ii. $25^{2-3}$ & $14+$ abbot & $11+$ abbot & 80 \\
\hline & 1491 & Visitation & CAP ii. $255^{-6}$ & $20+$ abbot & $18+$ abbot & 90.5 \\
\hline & 1494 & Visitation & CAP ii. 257 & $17+$ abbot & $16+$ abbot & 94 \\
\hline & 1497 & Visitation & CAP ii. $25^{8}$ & $17+$ abbot & $16+$ abbot & 94 \\
\hline & $15^{00}$ & Visitation & $C A P$ ii. 260 & $16+$ abbot & $14 / 15+$ abbot & 94 \\
\hline & $153^{8}$ & Dispensation & $F O R, 13^{6}$ & $13+$ abbot & $4+$ abbot & $3^{6}$ \\
\hline
\end{tabular}




\section{APPENDIX (Cont.)}

\begin{tabular}{|c|c|c|c|c|c|c|}
\hline Kingswood & 1379 & Taxation & TNA, E179/58/5 & $14+$ abbot & $10 / 11$ & 73 \\
\hline \multirow[t]{5}{*}{ Abbey } & 1538 & Dispensation & $F O R, 1_{31}^{1}$ & $13+$ abbot & non-monastic surnames & \\
\hline & 1538 & Pensions & $L P$ xiii/ $1,157-76 ; M A$ v. 429 & $12+$ abbot & non-monastic surnames & \\
\hline & $153^{8}$ & Pensions & $L P$ xiii/ 1,$68 ; M A$ v. 425 & $12+$ abbot & non-monastic surnames & \\
\hline & $153^{8}$ & Surrender & TNA, E $322 / 135 ; D K R$ viii, appendix ii, p. 25 & $12+$ abbot & non-monastic surnames & \\
\hline & $1538 ?$ & Pensions & TNA, $\mathrm{E}_{314} / 20 / 11$, fo. $1 \mathrm{~V}$ & $13+$ abbot & non-monastic surnames & \\
\hline Little Malvern & 1379 & Taxation & TNA, E1 $79 / 5^{8 / 11}$ & $9+$ prior & $6+$ prior & 70 \\
\hline \multirow[t]{3}{*}{ Priory } & 1534 & Supremacy & TNA, E25/83/2; DKR vii, appendix ii, p. 293 & $7+$ prior & $4+$ prior & 62.5 \\
\hline & $153^{8 ?}$ & Pensions & TNA, $\mathrm{E}_{31}{ }^{2} / 23^{2} ; L P$ xiii/ 1, no. $15^{20}$ & prior only & & \\
\hline & 1541 & Pensions & Bodl. Lib., Ms Tanner 343, p. 3 & 1 & & \\
\hline Llanthony & 1379 & Taxation & TNA, E179/58/5 & $18 ?+$ prior & $17+$ prior & 95 \\
\hline Secunda & 1408 & Election & TNA, C $1_{1} 5 / 76$, fos $7 \mathrm{r}-8 \mathrm{r}, 9 \mathrm{v}$ & 19 & 19 & 100 \\
\hline \multirow[t]{9}{*}{ Priory } & $143^{6}$ & Election & WRO, b7o6.o93-BA2648/6(i) p. 39 & $25 / 26+$ prior & $23 / 24+$ prior & $92 \cdot 5$ \\
\hline & 1457 & Election & Reg. Llanthony, 2 & $21+$ prior & $20+$ prior & $95 \cdot 5$ \\
\hline & 1498 & Visitation & Reg. Morton, ii. 130 & $19+$ prior & $16+$ prior & 85 \\
\hline & 1534 & Supremacy & TNA, E25/75; $D K R$ vii, appendix ii, p. 290 & $22+$ prior & $17 / 18+$ prior & 82 \\
\hline & $153^{8}$ & Dispensation & $F O R, 130$ & $23+$ prior & mixed surnames & \\
\hline & $153^{8}$ & Surrender & TNA, $\mathrm{E}_{322 / 135} ; D K R$ viii, appendix ii, p. 26 & $24+$ prior & 13 & $5^{6}$ \\
\hline & $1538 ?$ & Pensions & $\mathrm{TNA}, \mathrm{E}_{3} 14 / 20 / 11$, fo. $2 \mathrm{~V}$ & $18+$ prior +5 & 15 & 62.5 \\
\hline & $155^{2-3}$ & Pensions & $\begin{array}{l}\text { TNA, E } 101 / 76 / 14 \text {; Baskerville, 'The dispos- } \\
\text { sessed religious', 102, } 115,120,122\end{array}$ & 15 & 10 & 67 \\
\hline & $1555^{-6}$ & Pensions & BL, MS Add. 8102; TNA, E164/31 & 13 & 9 & 69 \\
\hline Pershore & $133^{8-9}$ & Visitation & Reg. sede vacante, $280 ; \mathrm{WCL}$, Ms $\mathrm{B} 670$ & $30+$ abbot & 17 & 55 \\
\hline \multirow[t]{3}{*}{ Abbey } & 1340 & Election & Reg. Bransford, 74 & $17+$ abbot & 11 & 61 \\
\hline & 1346 & Chantry & TNA, E $3^{1} 5^{/ 61}$, fo. $34^{\mathrm{V}-35^{\mathrm{r}} \text {; Reg. Bransford, }{ }_{1} 8}$ & $3^{0}+$ abbot & 20 & $64 \cdot 5$ \\
\hline & 1379 & Taxation & TNA, E179/58/11 & $20+a b b o t$ & $17+\mathrm{abbot}$ & 86 \\
\hline
\end{tabular}


APPENDIX (Cont.)

\begin{tabular}{|c|c|c|c|c|c|c|}
\hline House & Date & Type of list & Source & Monks total & Monks ordained & $\%$ \\
\hline & 1498 & Visitation & Reg. Morton, ii. 131 & $23+$ abbot & $20+a b b o t$ & $87 \cdot 5$ \\
\hline & 1534 & Pensions & TNA, E25/102/6; DKR vii, appendix ii, p. 298 & $20+$ abbot & $10+$ abbot & $5^{\mathrm{O}}$ \\
\hline & 1540 & Pensions & TNA, E $315 / 234$, fos $133^{\mathrm{r}-1} 3^{6 \mathrm{r} ;} L P \times \mathrm{xv} .54^{8}$ & $14+$ abbot & non-monastic surnames & \\
\hline & 1540 & Pensions & TNA, $\mathrm{E}_{315} / 245$, fo. $15^{\mathrm{O}} ; L P \times \mathrm{xv} .30 ; M A$ ii. 425 & $14+$ abbot & non-monastic surnames & \\
\hline & 1541 & Tax on pensions & Bodl. Lib., Ms Tanner 343 , p. 2 & $13+2$ abbot & non-monastic surnames & \\
\hline & $1555^{-6}$ & Pensions & BL, MS Add. 8102; TNA, E164/31 & 9 & non-monastic surnames & \\
\hline \multirow[t]{6}{*}{ Studley Priory } & 1379 & Taxation & $\mathrm{TNA}, \mathrm{E}_{179} / 5^{8 / 11}$ & $6+$ prior & $4+$ prior & 71.5 \\
\hline & 1498 & Visitation & Reg. Morton, ii. 133 & $5+$ prior & 5 & $8_{3}$ \\
\hline & $15^{11}$ & Visitation & Reg. Llanthony, 98 & $8+$ prior & 8 & 89 \\
\hline & 1534 & Supremacy & TNA, E25/107; DKR vii, appendix ii, p. 301 & $8+$ prior & $5 / 6+$ prior & 78 \\
\hline & 1537 & Dispensation & $F O R, 89$ & 8 & $2 / 3$ & 43 \\
\hline & $153^{8}$ & Pensions & TNA, $\mathrm{E}_{31} 5^{/ 232}$, fo. $4^{1 \mathrm{v}} ; L P \mathrm{xiii} / 2$, no. $15^{20}$ & prior only & & \\
\hline \multirow[t]{11}{*}{$\begin{array}{l}\text { Tewkesbury } \\
\text { Abbey }\end{array}$} & 1347 & Election & $\begin{array}{l}\text { Reg. Bransford, 161-6; Haines, Ecclesia } \\
\text { Anglicana, } 24\end{array}$ & $40+$ abbot & $3^{\mathrm{O}}+\mathrm{abbot}$ & $75 \cdot 5$ \\
\hline & 1361 & Election & Reg. sede vacante, $213-16$ & $10+$ abbot & $9+$ abbot & 91 \\
\hline & 1379 & Taxation & TNA, E1 $79 / 5^{8 / 54}$ & 27 & 23 & 85 \\
\hline & 1498 & Visitation & Reg. Morton, ii. 129 & $32+$ abbot & $27 / 28+$ abbot & 88 \\
\hline & 1534 & Supremacy & TNA, E25/109/1;DKR vii, appendix ii, p. 301 & $37+$ abbot & $27 / 29+$ abbot & 79 \\
\hline & $1539 / 40$ & Pensions & TNA, $\mathrm{E}_{315} / 245$, fo.159; LP Xv. 19 & $3^{8}+$ abbot & 32 & 82 \\
\hline & 1540 & Pensions & $\begin{array}{l}\text { TNA, E } 315 / 494 / 1 \text { fo. } 83 \text {; Baskerville, 'The } \\
\text { dispossessed religious', } 84-6\end{array}$ & $3^{8+\text { abbot }}$ & $3^{\mathrm{o}}+\mathrm{abbot}$ & $79 \cdot 5$ \\
\hline & 1540 & & $\begin{array}{l}\text { TNA, } \mathrm{E}_{315} / 234 \text {, fos } 279 \mathrm{r}, 33^{6 r-342 v} \text {; } L P \mathrm{xv} \text {. } \\
553\end{array}$ & $35+2+$ abbot & $26+$ abbot & 69 \\
\hline & 1540 & Ex-religious & WRO, Bell's Book, 245 & 14 & $10 ?$ & 71.5 \\
\hline & $155^{2-3}$ & Pensions & $\begin{array}{l}\text { TNA, E101/76/14; Baskerville, 'The dispos- } \\
\text { sessed religious', 103, 115, } 122\end{array}$ & 18 & & \\
\hline & $1555^{-6}$ & Pensions & BL, MS Add. 8102; TNA, E164/31 & 18 & 14 & 78 \\
\hline
\end{tabular}




\begin{tabular}{|c|c|c|c|c|c|c|}
\hline Warwick, St & $133^{8-9}$ & Visitation & Reg. sede vacante, $280-1$ & $9+$ prior & 5 & $5^{\mathrm{O}}$ \\
\hline \multirow[t]{5}{*}{ Sepulchre’s } & 1379 & Taxation & TNA, E179/58/11 & $4+$ prior & 3 & 60 \\
\hline & 1498 & Visitation & Reg. Morton, ii. 132 & $3+$ prior & $1+$ prior & $5^{0}$ \\
\hline & $153^{8}$ & Pensions & TNA, $\mathrm{E}_{3}{ }^{1}{ }^{/ 2} 3^{2}$, fo. $4^{2 \mathrm{r}} ; L P$ xiii/ 1 , no. $15^{20}$ & prior only & & \\
\hline & 1534 & Supremacy & TNA, E25/113; DKR vii, appendix ii, p. 303 & 2 & 2 & 100 \\
\hline & $1555^{-6}$ & Pensions & BL, Ms Add. 8102; TNA, E164/31 & 1 & & \\
\hline \multirow{13}{*}{$\begin{array}{l}\text { Winchcombe } \\
\text { Abbey }\end{array}$} & $135^{2}$ & Election & WRO, b7o6.o93-BA 2648/(i) p. 110,114 & $19+$ abbot & $18+$ abbot & 95 \\
\hline & 1379 & Taxation & TNA, E179/58/54 & 21 & 19 & 90.5 \\
\hline & 1395 & Election & Reg. sede vacante, $3^{66-7}$ & $18+$ abbot & $18+$ abbot & 100 \\
\hline & 1423 & Election & WRO, Reg. Morgan, 110 ; Haigh, Historia, $15^{1}$ & $19+$ abbot & $16+$ abbot & 85 \\
\hline & 1498 & Visitation & Reg. sede vacante, ii. $13^{1}$ & $24+$ abbot & $22 / 23+$ abbot & 96 \\
\hline & 1534 & Supremacy & TNA, E25/120/1; DKR vii, appendix ii, p. 304 & $24+$ abbot & $21+$ abbot & 88 \\
\hline & c.1534 & Visitation & LPL, Cartae Antique et Misc xi. $5^{6}$ & $24+$ abbot & $21+$ abbot & 88 \\
\hline & 1539 & Pensions & $\begin{array}{l}\text { TNA, } \mathrm{E}_{31} 15 / 494 / 1 \text {, fo. } 75 \text {; Baskerville, 'The } \\
\text { dispossessed religious', } 86-7\end{array}$ & $17+$ abbot & $15+$ abbot & 89 \\
\hline & $1539 / 40$ & Pensions & TNA, $\mathrm{E}_{315} / 245$, fo. 154 & $16+$ abbot & non-monastic surnames & \\
\hline & 1540 & Pensions & TNA, E $315 / 234$, fos $155^{\mathrm{v}-16 \text { or; } L P \times v . ~} 549$ & $17+$ abbot & non-monastic surnames & \\
\hline & 1540 & Ex-religious & WRO, Bell's Book, p. [246] & 9 & non-monastic surnames & \\
\hline & $155^{2-3}$ & Pensions & $\begin{array}{l}\text { TNA, E101/76/14; Baskerville, 'The dispos- } \\
\text { sessed religious', 101, } 114\end{array}$ & 13 & non-monastic surnames & \\
\hline & $1555^{-6}$ & Pensions & BL, MS Add. 8102; TNA, E164/31 & 14 & non-monastic surnames & \\
\hline \multirow{5}{*}{$\begin{array}{l}\text { Worcester } \\
\text { Cathedral } \\
\text { Priory }\end{array}$} & 1317 & Election & WCL, Reg A.5, fos $83^{r-v}$ & $47+$ prior & 7 & 14.5 \\
\hline & 1373 & Election & Reg. sede vacante, p. 290 & $3^{1}+$ prior & $25+$ prior & 81 \\
\hline & 1379 & Taxation & TNA, E1 $79 / 5^{8 / 11}$ & $32 ?+$ prior & $21 ?+$ prior & 66 \\
\hline & 1401 & Election & Reg. sede vacante, $37^{2-3}$ & $43+$ prior & $35+$ prior & 82 \\
\hline & $14^{19}$ & Election & Reg. sede vacante, 407 & $39+$ prior & $34+$ prior & $87 \cdot 5$ \\
\hline
\end{tabular}




\begin{tabular}{|c|c|c|c|c|c|c|}
\hline House & Date & Type of list & Source & Monks total & Monks ordained & $\%$ \\
\hline & 1433 & Election & Reg. sede vacante, $43^{1-3}$ & $44+$ prior & $39+$ prior & 89 \\
\hline & 1498 & Visitation & Reg. Morton, ii. 128 & $43+$ prior & $42+$ prior & 98 \\
\hline & $15^{21}$ & Visitation & LPL, Reg. Warham, fo. $293 \mathrm{v}$ & $4^{1}$ & $33 / 34+$ prior & 85 \\
\hline & $15^{25} / 26$ & Taxation & WCL, Reg. A.12, fo. 125 & $39+$ prior & $33+$ prior & 85 \\
\hline & $1531 / 32$ & Taxation & WCL, Reg. A.12, fo. 135 & $39+$ prior & & \\
\hline & 1534 & Supremacy & TNA, E25/122/3; DKR vii, appendix ii, p. 305 & $40+$ prior & $34+$ prior & 85 \\
\hline & 1535 & Names in letter & $L P$ ix, no. 653 & 29 & $23 / 24$ & 83 \\
\hline & 1536 & Election & WCL, Reg. A.6(iii), fo. 1 & $34+1+$ prior & $28+1$ & 80.5 \\
\hline & $1539-40$ & Pensions & TNA, $\mathrm{E}_{315} / 245$, fo. $8 \mathrm{r}$ & 11 & & \\
\hline & 1540 & Pensions & $L P \mathrm{xv}$, no. 81 & 11 & 9 & \\
\hline & 1540 & Pensions & 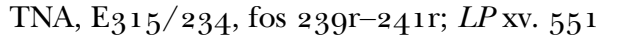 & 11 & & \\
\hline & 1540 & Ex-religious & WRO, Bell's Book, 214 & 25 & 20 & 80.5 \\
\hline & $1555^{-6}$ & Pensions & BL, MS Add. 8102; TNA, E164/31 & $9+1$ & $8+1$ & 90 \\
\hline
\end{tabular}

Sources: G. Baskerville, 'The dispossessed religious after the suppression of the monasteries', Transactions of the Bristol and Gloucestershire Archaeological Society xlix (1927), 63-122; A calendar of the registers of the priory of Llanthony by Gloucester, I457-1466, I50I-1525, ed. J. Rhodes (Bristol and Gloucestershire Archaeological Society, Gloucestershire Record Series xv, 2002); Cartae antique et misc, LPL, xi.56; GCL, reg. Malvern I (D), fos 2v-[46]; GCL, reg. C (Newton), fos 2r-33r; Roy Martin Haines, Ecclesia Anglicana: studies in the English Church of the later Middle Ages, Toronto 1989; 'Matthew Bible', Almonry Museum and Tourist Information Centre, Evesham; Register of Archbishop Warham, LPL, ii, fo. 293v; Arthur Sabin, 'Computus rolls of St Augustine's Abbey, Bristol, for the years 15 o3-4 and ${ }_{15}$ o6-7', Transactions of the Bristol and Gloucestershire Archaeological Society lxxiii (1954), 192-207; C. S. Taylor, 'The religious houses of Bristol and their dissolution', Transactions of the Bristol and Gloucestershire Archaeological Society xxix (19o6), 81-1 26; Two computus rolls of Saint Augustine's Abbey, Bristol, for I $49 I_{-2}$ and I 5 II-I2, ed. Gwen Beachcroft and Arthur Sabin (Bristol Record Society Publication ix, 1938); WRO, 802.BA2764 (Liber visitationis [Bell's Book]); WRO, b7o6.o93-BA2648/6(i) (reg. Boughier); WRO, b7o6.o93BA2648/3(ii); WRO, b7o6.o93-BA2648/5(iii) (reg. Morgan)

* There is one obscure name in this list of Evesham monks, possibly written in a hand other than that of brother John Alcester, which David Knowles read as John Slye, but to me is unclear: M. D. Knowles and Thurston Dart, 'Notes on a Bible of Evesham Abbey', EHR lxxix (1964), $775^{-8}$. I am grateful to Ashleigh Jayes, manager of the Almonry Museum and Tourist Information Centre, for her help with this interesting document. 